\title{
Biomass and Bioenergy
}

\section{Integral valorization of cellulosic and hemicellulosic sugars for biobutanol production: $A B E$ fermentation of the whole slurry from microwave pretreated brewer's spent grains --Manuscript Draft--}

\begin{tabular}{|c|c|}
\hline Manuscript Number: & \\
\hline Article Type: & Research paper \\
\hline Keywords: & $\begin{array}{l}\text { brewing industry waste; lignocellulosic biomass; microwave pretreatment; slurry; } \\
\text { bioenergy; Clostridium beijerinckii }\end{array}$ \\
\hline Corresponding Author: & $\begin{array}{l}\text { Mónica Coca, PhD } \\
\text { University of Valladolid } \\
\text { Valladolid, SPAIN }\end{array}$ \\
\hline First Author: & Juan C. López-Linares \\
\hline Order of Authors: & Juan C. López-Linares \\
\hline & M.Teresa García-Cubero \\
\hline & Susana Lucas \\
\hline & Mónica Coca, PhD \\
\hline Abstract: & $\begin{array}{l}\text { In this study, an innovative approach is proposed for the integral valorization of all } \\
\text { sugars (cellulosic and hemicellulosic) contained in a lignocellulosic residue, as is } \\
\text { brewer's spent grain (BSG), through the production of an advanced biofuel such as } \\
\text { biobutanol. For this purpose, the entire slurry obtained in the microwave assisted dilute } \\
\text { sulfuric acid pretreatment under optimized conditions }\left(147^{\circ} \mathrm{C}, 2 \text { min and } 1.26 \% \mathrm{H} 2\right. \\
\text { SO } 4 \text { ) at a biomass loading as high as } 15 \%(\mathrm{w} / \mathrm{v}) \text { was enzymatically hydrolyzed } \\
\text { without previous solid-liquid separation and the highly concentrated solution of sugars } \\
\text { recovered was fermented to butanol by Clostridium beijerinckii . In this way, all sugars } \\
\text { (pentoses and hexoses) contained in BSG could be fermented using a single } \\
\text { bioreactor, leading to } 11 \mathrm{~g} / \mathrm{L} \text { of butanol. The mass balance revealed than an overall } \\
\text { yield of } 91 \mathrm{~kg} \text { butanol/t BSG and } 138 \mathrm{~kg} \text { ABE/t BSG could be reached. }\end{array}$ \\
\hline Suggested Reviewers: & $\begin{array}{l}\text { Mohamed Hemida Abd-Alla } \\
\text { Assiut University } \\
\text { mabdalla@sci.mak.ac.ug } \\
\text { Expertise on ABE fermentation }\end{array}$ \\
\hline & $\begin{array}{l}\text { Reyna Gomez-Flores } \\
\text { University of Western Ontario } \\
\text { rgomezf@ @uwo.ca } \\
\text { Expertise on ABE fermentation }\end{array}$ \\
\hline & $\begin{array}{l}\text { Maryam Davaritouchaee } \\
\text { Washington State University } \\
\text { m.davaritouchaee@wsu.edu } \\
\text { Expertise on biomass pretreatment }\end{array}$ \\
\hline & $\begin{array}{l}\text { Sibel Irmak } \\
\text { University of Nebraska } \\
\text { sibel.irmak@unl.edu } \\
\text { Expertise on biomass prtreatment }\end{array}$ \\
\hline & $\begin{array}{l}\text { Duncan J. Macquarrie } \\
\text { University of York } \\
\text { duncan.macquarrie@york.ac.uk } \\
\text { Expertise on biomass pretreatment }\end{array}$ \\
\hline Opposed Reviewers: & \\
\hline
\end{tabular}


1 Integral valorization of cellulosic and hemicellulosic sugars for biobutanol

2 production: $\mathrm{ABE}$ fermentation of the whole slurry from

3 microwave pretreated brewer`s spent grains

4 Juan C. López-Linares ${ }^{\mathrm{a}, \mathrm{b}}$, M.Teresa García-Cubero ${ }^{\mathrm{a}, \mathrm{b}}$, Susana Lucas ${ }^{\mathrm{a}, \mathrm{b}}$, Mónica Coca ${ }^{\mathrm{a}, \mathrm{b},{ }^{*}}$

$5 \quad{ }^{a}$ Institute of Sustainable Processes. University of Valladolid, Spain

$6 \quad{ }^{\mathrm{b}}$ Department of Chemical Engineering and Environmental Technology, School of

7 Industrial Engineering, University of Valladolid, Dr. Mergelina, s/n, Valladolid, Spain 8

* Corresponding author. Department of Chemical Engineering and Environmental Technology, University of Valladolid, Dr. Mergelina s/n, 47011, Valladolid (Spain). E-mail address: monica@iq.uva.es (Mónica Coca). 


\section{ABSTRACT}

In this study, an innovative approach is proposed for the integral valorization of all sugars (cellulosic and hemicellulosic) contained in a lignocellulosic residue, as is brewer's spent grain (BSG), through the production of an advanced biofuel such as biobutanol. For this purpose, the entire slurry obtained in the microwave assisted dilute sulfuric acid pretreatment under optimized conditions $\left(147^{\circ} \mathrm{C}, 2\right.$ min and $\left.1.26 \% \mathrm{H}_{2} \mathrm{SO}_{4}\right)$ at a biomass loading as high as $15 \%(\mathrm{w} / \mathrm{v})$ was enzymatically hydrolyzed without previous solid-liquid separation and the highly concentrated solution of sugars recovered was fermented to butanol by Clostridium beijerinckii. In this way, all sugars (pentoses and hexoses) contained in BSG could be fermented using a single bioreactor, leading to $11 \mathrm{~g} / \mathrm{L}$ of butanol. The mass balance revealed than an overall yield of $91 \mathrm{~kg}$ butanol/t BSG and $138 \mathrm{~kg} \mathrm{ABE/t} \mathrm{BSG} \mathrm{could} \mathrm{be} \mathrm{reached.}$

Keywords: brewing industry waste; lignocellulosic biomass; microwave pretreatment; slurry; bioenergy; Clostridium beijerinckii.

\section{Introduction}

The development of renewable energy sources which allow emissions of greenhouse gases and the risks related to dependence on fossil fuels in the transport sector to be reduced is essential. In this sense, Directive (EU) 2015/1513 of the European Parliament and of the Council, of 9 September [1], aims to encourage research into so-called advanced biofuels, which can be obtained from lignocellulosic biomass.

Biobutanol, which can be obtained from lignocellulosic residues by anaerobic fermentation with Clostridia strains in what is known as acetone-butanol-ethanol (ABE) 
34 fermentation, nowadays has increased importance due to its application as an industrial chemical and advanced biofuel $[2,3]$. Biobutanol has an energy content comparable to gasoline and higher than ethanol, a low corrosive nature and is safer to handle due to its lower vapor pressure in comparison with ethanol. Therefore, gasoline might be partial or totally replaced by butanol, since existing engines do not need any modifications. In addition, butanol can be used as a chemical commodity in different industries, such as enamels, lacquers, antibiotics, pharmaceuticals, food and flavoring [4,5].

Brewer spent grain (BSG) is an interesting lignocellulosic residue, accounting for $85 \%$ of the total waste generated in breweries [6,7]. Considering the European Union and the world, the production of beer in 2014 was 37.4 and 180.3 million tonnes, respectively [8]. The typical ratio of wet $\mathrm{BSG}$ is $20 \mathrm{~kg}$ produced per $100 \mathrm{~L}$ beer. Although BSG can be used as feed for livestock, nowadays its commercial application is limited. Therefore, it could be used to produce liquid biofuels such as butanol through biological processes due to its carbohydrate content, about 50\% [9].

BSG has a complicated structure, mainly formed by cellulose, hemicellulose and lignin [10]. Then, in order to produce biobutanol from BSG, different steps (pretreatment, enzymatic hydrolysis and fermentation) have to be carried out. The most essential step is the pretreatment, since it is necessary to overcome the recalcitrance of lignocellulose and reduce the cellulose crystallinity for improving sugar released in the subsequent enzymatic hydrolysis. A great number of pretreatments have been developed, such as liquid hot water, dilute acid, alkaline, ionic liquids, ozone, microwave, steam explosion or fungal, among others $[11,12]$. In industries, the most usually applied process is the dilute acid pretreatment, as it is able to obtain hemicellulose recoveries of about $85-95 \%$; the pretreated solid is enriched in cellulose, which is more accessible to enzymes, reducing enzyme loads; and it is economically 
59 feasible $[13,14]$. However, dilute acid pretreatment has the disadvantage that it is

60 necessary to use high temperatures and long process times [15]. In order to mitigate these long process times and get a higher homogeneity in the heating process, the dilute acid pretreatment can be used in combination with microwave, which is an interesting emerging technology that is substituting conventional heating. Microwave pretreatment is able to induce heat at the molecular level by the direct transformation of microwave irradiation into energy. Therefore, energy can be homogeneously dispersed through the material, while an overheating of the outside surface with some cooler inside areas can occur in conventional heating. Thus, in comparison with the simple dilute acid, dilute acid pretreatment assisted by microwave is simpler, more homogeneous, more energy efficient, profitable, environmentally friendly and is able to withdraw larger amounts of acetyl groups from the hemicellulose. What is more, unlike the single dilute acid pretreatment, the dilute acid pretreatment combined with microwave is faster [16-18]. The combined acid-microwave pretreatment has been applied to different feedstocks (such as maize distillery stillage, macroalgal Laminaria japonica, or water hyacinth) to produce bioethanol and biohydrogen [19-21]. No previous references about butanol production from lignocellulosic biomass after microwave pretreatment catalyzed by dilute acid have been found.

It is worth mentioning that, after the lignocellulosic biomass pretreatment, the solid and liquid fractions are usually separated, fermenting only the sugars from the pretreated solid and throwing away the liquid fraction due to its low sugar concentration. However, the use of higher sugar concentrations is essential and this can be achieved by using the slurries generated in the pretreatment of lignocellulosic biomass. In addition, there are many other reasons that considerably increase the importance of using slurries; for instance, their use allows a single bioreactor to be used, 
84 avoiding filtration processes to separate the solid and prehydrolysate originated, and

preventing independent fermentation stages. In this way, a liquor containing both pentoses (xylose, arabinose) and hexoses (glucose, galactose) can be obtained as a result

of using the whole slurry in the pretreatment and subsequent enzymatic hydrolysis process, which can be used as the substrate in $\mathrm{ABE}$ fermentation [22].

This work aims to propose a process based on microwave assisted dilute sulfuric acid pretreatment to recover sugars from BSG and to obtain a slurry which is highly concentrated in pentoses and hexoses and which could be transformed to biobutanol in a single fermenter. So, the operating conditions of the microwave pretreatment in dilute sulfuric acid were firstly optimized to maximize the recovery of fermentable sugars from both the hemicellulose and cellulose fractions. Secondly, the whole slurry from the pretreatment was enzymatically hydrolyzed to obtain a solution rich in sugars that could be further fermented to butanol by Clostridium beijerinckii DSM 6422. Then, in order to increase the concentration of fermentable sugars, and therefore to improve the butanol concentration, the pretreatment was conducted under optimal conditions at two different solid loadings (10 and $15 \% \mathrm{w} / \mathrm{v}$ ). The main novelty of the work is the use of an emergent pretreatment as microwave for the integral valorization of hemicellulosic and cellulosic sugars in low value lignocellulosic biomass through the production of an advanced biofuel such as biobutanol.

\section{Materials and methods}

\subsection{Raw material}

BSG was kindly provided by a local brewery (Cerveza Milana, Valladolid) and stored frozen at $-20^{\circ} \mathrm{C}$ until being used. Prior to its use, the BSG was water washed, dried at $50^{\circ} \mathrm{C}$, ground (particle size lower than $1 \mathrm{~mm}$ ) and homogenized. The feedstock 
109

110 hemicellulose: $28.7 \pm 0.8$; starch: $2.1 \pm 0.0$; acid lignin: $25.8 \pm 1.2$; extractives: $2.3 \pm$

$111 \quad 0.1$; ash: $2.7 \pm 0.1[23]$.

112

\subsection{Microwave assisted dilute sulfuric acid pretreatment}

Microwave pretreatment of BSG was carried out in a Multiwave PRO SOLV reactor $50 \mathrm{~Hz}$ (Anton Paar GmbH, Austria, Europe) at 10\% w/v as described elsewhere [23].

After pretreatment, the pretreated BSG was separated from the liquid fraction by vacuum filtration, water washed, dried at $40^{\circ} \mathrm{C}$ and weighed to calculate the solid recovery (g pretreated solid per $100 \mathrm{~g}$ untreated BSG). The pretreated BSG was used in enzymatic hydrolysis assays, and its composition in carbohydrates and lignin was determined. The pretreatment liquids were characterized for fermentable sugars and potential inhibitors (organic acids, furans and phenolic compounds). The recovery of carbohydrates in the pretreatment liquid was calculated as previously explained [23].

\subsection{Experimental design}

A central composite experimental design was planned $(\alpha=1.414)$ to determine the optimum experimental conditions that maximize sugar recovery from BSG.

Temperature $\left(120-170^{\circ} \mathrm{C}\right)$, time (2-10 min) and sulfuric acid concentration $(0.5-1.5 \%$, w/v) were selected as factors (Table 1). The intervals of the variables were selected on the basis of previous results [24]. 20 experimental runs were performed, including one point and five replications. Statgraphics Centurion XVIII was used to plan the design and analyze the experimental data.

The Combined Severity Factor (CSF) was calculated as proposed by MacAskill et al. [25] (Eq. 1) as indicator of the severity of the pretreatment conditions: 


$$
\text { Combined Severity Factor }(\mathrm{CSF})=\log \left[t \times \exp \left(\frac{T-100}{14.75}\right)\right]-\mathrm{pH}
$$

where $\mathrm{t}$ is time (min), $\mathrm{T}$ is temperature $\left({ }^{\circ} \mathrm{C}\right)$ and the $\mathrm{pH}$ is that of the initial sulfuric acid solution used in each run.

\subsection{Enzymatic hydrolysis}

Pretreated solids obtained in the experimental design were used as substrate in the enzymatic hydrolysis (EH) assays, which were carried out at a solid loading of $5 \%$ $(\mathrm{w} / \mathrm{v})$ at $50^{\circ} \mathrm{C}$ for $48 \mathrm{~h}$ in an orbital shaker as described elsewhere [23]. The enzyme complex used was Cellic CTec2, kindly provided by Novozymes (Denmark), being the enzyme load employed of 15 Filter Paper Units (FPU)/g solid. Samples were taken at 24 and 48h, centrifuged and analyzed for monosaccharides and degradation products.

Glucose recovery in enzymatic hydrolysis (referred to pretreated or untreated BSG) was calculated considering the glucose in the enzymatic hydrolysates and the glucose in the pretreated or non-pretreated lignocellulosic material, as previously described [23].

In order to confirm optimization results, enzymatic hydrolysis essays were carried out with the pretreated BSG obtained under optimal conditions. In addition, to increase the sugar concentrations in hydrolysates, the solid loading in the pretreatment was also increased to $15 \% \mathrm{w} / \mathrm{v}$. What is more, in order to obtain a sugar solution rich in pentoses and hexoses which can be used in ABE fermentation, the whole slurry obtained under optimal pretreatment conditions (at 10 and $15 \%$ solid loading of pretreatment) was enzymatically hydrolyzed using 1 L flasks with $400 \mathrm{~mL}$ of slurry $(4.8$ and $7.9 \%$ insoluble solid concentration for 10 and $15 \%$ solid loading in pretreatment, respectively). Moreover, sodium citrate buffer was not added, and water was used as the solvent at $\mathrm{pH} 4.8$, which was adjusted with solid $\mathrm{NaOH}$. After saccharification, vacuum 
158 filtration was used to separate liquid and solid phases. The solid phase was water

159 washed, dried at $40{ }^{\circ} \mathrm{C}$ and analyzed for residual sugars and lignin. For the liquid phase

160 (slurry enzymatic hydrolysate), monosaccharides and degradation products were

161 determined, as well as its suitability as substrate in ABE fermentation.

\subsection{Microorganism, detoxification and ABE fermentation}

C. beijerinckii DSM 6422, which is a microorganism acquired from the German collection (DSMZ, Leibniz, Germany), was maintained and grown as previously described [23].

Slurries from the microwave acid pretreatment under optimal conditions at 10 and $15 \%(\mathrm{w} / \mathrm{v})$ BSG concentrations were enzymatically hydrolyzed as described in section 2.4. Then, the resulting slurry enzymatic hydrolysates rich in sugars from hemicellulose and cellulose were transformed into biobutanol with $C$. beijerinckii.

Before fermentation, the enzymatic hydrolysates were detoxified with powder activated charcoal or ion-exchange resins (Lewatit S4528) under conditions selected from previous experimental runs (data not shown). The enzymatic hydrolysates were mixed with activated charcoal or ion-exchange resins at a ratio of $2 \%, 5 \%$ or $10 \%(\mathrm{w} / \mathrm{v})$ in an orbital shaker (Comecta Optic Ivymen system) at $35^{\circ} \mathrm{C}$. The activated charcoal detoxification was carried out at $130 \mathrm{rpm}$ and $1.5 \mathrm{~h}$, whereas the ion-exchange resin treatment was performed at $150 \mathrm{rpm}$ for $24 \mathrm{~h}$. Prior to the detoxification, the ionexchange resin was conditioned with a $70 \mathrm{~g} / \mathrm{L} \mathrm{NaOH}$ solution for $24 \mathrm{~h}$, recovered by vacuum filtration, washed with distilled water and dried at $40{ }^{\circ} \mathrm{C}$. After detoxification, the mixtures were vacuum filtered and the hydrolysates were analyzed. Afterward, ABE fermentation with $C$. beijerinkii was conducted at $35^{\circ} \mathrm{C}$ and $135 \mathrm{rpm}$ for $120 \mathrm{~h}$. The initial $\mathrm{pH}$ of the fermentation was 5.5, and that was not controlled during the 
183 fermentation process (for more details, see Plaza et al. [26]). Fermentation runs were

184 performed in triplicate.

185

186

187 applied.

\subsection{Analytical methods}

In order to determine the composition of BSG before and after pretreatment the analytical methods of the National Renewable Energy Laboratory (NREL) [27,28] were

High Performance Liquid Chromatography (HPLC) based on refractive index (Waters 2414) and photodiode array detection (DAD Waters 996) was the analytic technique used to measure the concentrations of monosaccharides (glucose, xylose and arabinose), potential fermentation inhibitors (acetic acid, formic acid, furfural and hydroxymethylfurfural (HMF)) and ABE products (acetone, butanol, ethanol and butyric acid). The description of the analytical procedure can be found in a previous work [23].

On the other hand, an acid hydrolysis process $\left(120{ }^{\circ} \mathrm{C}, 3 \% \mathrm{w} / \mathrm{v} \mathrm{H}_{2} \mathrm{SO}_{4}, 30 \mathrm{~min}\right)$ was applied to quantify the oligomeric sugar concentration in the liquid fractions obtained as a consequence of the BSG microwave pretreatment. Oligomer composition was calculated through the difference between the total free monosaccharides in the hydrolysates before and after the acid hydrolysis step. The total content of phenolic compounds was measured by the Folin-Ciocalteu method [29]. Analytical determinations were carried out in triplicate and the average results are shown.

\section{Results and discussion}

\subsection{Effect of microwave pretreatment assisted by dilute sulfuric acid on BSG}


First, an experimental design was planned to select the operating conditions that

could maximize the recovery of sugars (hemicellulosic and cellulosic). The CSF factor, which takes into account the influence of such operating factors as temperature, time and acid concentration, was employed to analyze the results.

Solid recoveries corresponding to the experimental runs carried out are shown in Table 2. In general, the solid recovery decreased when the CSF factor increased. Then, solid recoveries ranged from $37 \%$ to $87 \%$, corresponding to one of the most severe ( $\mathrm{CSF}=2.71$, run 14) and less severe ( $\mathrm{CSF}=0.37$, run 9), respectively. As a result of the pretreatment, all pretreatment conditions assayed led to pretreated solids enriched in cellulose. This fact is due to the solubilization of extractives and hemicellulosic components in the liquid fraction. On the other hand, Table 2 also shows glucose recoveries in the pretreated solids $\left(\mathrm{GR}_{\mathrm{s}}\right)$. The highest recovery $(\mathrm{GRs}=76 \%)$ corresponded to soft pretreatment conditions $(\mathrm{CSF}=0.37$, run 9). However, when the pretreatment was carried out at harshness conditions $(\mathrm{CSF}=2.84$, run 19$)$, a $\mathrm{GR}_{\mathrm{S}}$ as low as $54 \%$ was achieved. The lignin in the pretreated solid fractions also increased, which might be due to formation of lignin-like structures from condensation reactions [30]. Regarding the hemicellulose content in the pretreated solids (Table 2), its complete solubilization $\left(\mathrm{HSR}_{\mathrm{s}}=0 \%\right)$ was achieved for the highest combined severity pretreatment (CSF > 2, runs 14, 18 and 19). Nevertheless, when the CSF was lower than 1, a considerable content of hemicellulose fraction was observed in the pretreated BSG (15-19\%), which could negatively influence the subsequent enzymatic hydrolysis process, due to the greater difficulty for the enzymes to get into contact with the cellulose [31].

A pH ranging from 0.3 (runs 6,11 and 13) to 2.3 (run 1) was measured in the liquid fractions (Table 3), corresponding to the highest and the lowest sulfuric acid 
232 concentrations (1.5-1.84 and $0.16 \%$ ), respectively. The monosaccharide concentrations

233 (glucose, xylose and arabinose), as well as the sugar recoveries $\left(\mathrm{GR}_{\mathrm{L}}, \mathrm{HSR}_{\mathrm{L}}\right.$ ) in the

234 liquid fractions are summarized in Table 3. In this way, it can be seen that the sugar concentrations ranged from $7.3 \mathrm{~g} / \mathrm{L}$ (run 9) to $33.2 \mathrm{~g} / \mathrm{L}$ (runs 5, 6 and 17), mainly in monomeric form (Table 3). Glucose was detected in the liquid fractions, even at the

237 softest pretreatment conditions (runs 1, 4, 7, 9, 13 and 15, CSF $<1$ ), due to the content of non-structural glucose (glucose in extractives and starch) and amorphous cellulose, which is easily solubilizable [32]. On the contrary, arabinose and xylose were the majority sugars, being measured the highest concentrations for CSF $=1.60$ (run 5). This

same behavior was also observed for hemicellulosic sugar recoveries in the liquid

242 fraction $\left(\mathrm{HSR}_{\mathrm{L}}\right)$. Nevertheless, due to hemicellulosic sugar degradation reactions,

xylose concentrations and hemicellulosic sugar recoveries diminished when the

244 pretreatment was carried out at CSF > 2 (runs 2, 14, 18 and 19). It should be noted that

when the pretreatment was performed at low $\operatorname{CSF}(\mathrm{CSF}=0.02$ and 0.37 , runs 15 and 9),

pretreatment conditions were not severe enough to get the solubilization of the

247 hemicellulose contained in BSG.

Compounds such as acetic and formic acids, furfural, HMF and phenolic compounds originate in the pretreatment (Table 4). At low pretreatment severities (CSF $<1$, runs 1 ,

4, 7, 9, 13 and 15), inhibitor concentrations (except acetic acid and total phenols) were

very low or even not detected. Furfural and total phenol concentrations of up to 3.84 and $2.43 \mathrm{~g} / \mathrm{L}$ were detected in the liquid fractions at the highest $\mathrm{CSF}$ (run 19, CSF = reported by Rojas-Chamorro et al. [32] in the phosphoric acid pretreatment of BSG, which could be more suitable for the subsequent fermentation process. 
257

\subsection{Enzymatic hydrolysis experiments of BSG pretreated by microwave}

The pretreated solid fractions obtained in the experimental design were used in enzymatic hydrolysis assays (at 5\% w/v solid load) to assess the effectiveness of the microwave pretreatment assisted by dilute sulfuric acid in the release of glucose from cellulose.

Table 5 shows glucose and xylose concentrations obtained in the enzymatic hydrolysates, which range from 3.4 to $18.1 \mathrm{~g} / \mathrm{L}$ and 0.3 to $3.0 \mathrm{~g} / \mathrm{L}$, respectively. In this way, the highest glucose concentration and glucose recovery (referred to pretreated BSG) (18.1 g/L and 100\%, respectively) were obtained for a CSF of 2.01 (run 18: 170 ${ }^{\circ} \mathrm{C}, 2 \mathrm{~min}, 1.5 \% \mathrm{H}_{2} \mathrm{SO}_{4}$ ), the recovery of glucose being four times higher than those achieved when the enzymatic hydrolysis was applied to non-pretreated BSG (25.6\%) [23]. However, when the CSF was higher than 2.01, lower glucose concentrations and EH glucose recovery (referred to pretreated BSG) were obtained, probably due to glucose degradation [33].

Rojas-Chamorro et al. [32] also observed an almost complete conversion of cellulose to glucose in BSG pretreated under acid conditions $\left(155^{\circ} \mathrm{C}, 0\right.$ min and $\left.2 \% \mathrm{H}_{3} \mathrm{PO}_{4}\right)$. Fernández-Delgado et al. [34] pretreated BSG with peroxide alkaline, obtaining an glucose recovery (referred to pretreated material) of $98 \%\left(50^{\circ} \mathrm{C}, 60 \mathrm{~min}, 5 \% \mathrm{H}_{2} \mathrm{O}_{2}, \mathrm{pH}\right.$ 11.5). However, lower values (60-69\%) were obtained when the BSG was pretreated with $\mathrm{NaOH}\left(120^{\circ} \mathrm{C}, 30 \mathrm{~min}\right)$ or ozone $\left(2.7 \% \mathrm{O}_{3}, 30 \mathrm{~min}\right)$. Microwave pretreatment, assisted by alkaline or deep eutectic solvent, has also been applied with other lignocellulosic materials (wheat straw, Miscanthus, switchgrass or corn stover), yielding lower saccharification values (about 70\%) [35,36], probably due to the use of limited domestic microwave ovens instead of multiwave closed reactors, as multiwave closed 
281 reactors allow a better control of the pretreatment conditions, as well as the use of

282 higher temperatures and pressures.

283 Table 5 also summarized the EH glucose recovery referred to the glucose in the non-

284 pretreated BSG. As BSG contains starch and non-structural glucose, which are

285 effortlessly hydrolyzed in the pretreatment, only the glucose contained as cellulose has

286 been considered to determine the EH glucose recovery (referred to untreated BSG) [37].

287 Although high recoveries (average 67\%) were found around the central point $\left(145^{\circ} \mathrm{C}, 6\right.$

$288 \mathrm{~min}, 1 \% \mathrm{H}_{2} \mathrm{SO}_{4}$ ), it can be said that the highest $\mathrm{EH}$ glucose recovery (referred to

289 untreated BSG) (72\%) was obtained when the pretreatment was carried out at a

290 combined severity of 1.93 (run 3). However, for CSF > 1.93, EH glucose recovery

291 (referred to untreated BSG) decreased, probably due to glucose degradation.

292 A similar maximum EH glucose recovery (referred to untreated BSG) (about 74-

$29375 \%$ ) was obtained in the microwave assisted hydrothermal pretreatment of BSG (at

$294192.7^{\circ} \mathrm{C}$ for $5.4 \mathrm{~min}$ ) [23] and in the microwave-assisted dilute sulfuric acid

295 pretreatment of maize distillery stillage (300 W, 3.7 atm, $\left.15 \mathrm{~min}, 1.96 \% \mathrm{H}_{2} \mathrm{SO}_{4}\right)$ [19].

296 The overall sugar recovery (Table 5) takes into account the concentration of sugars in

297 the liquid fractions and the glucose and xylose in enzymatic hydrolysates, with regard to

298 the total sugar content in the untreated BSG. The highest recovery $(87.4 \%)$ was

299 achieved at the central point $\left(145^{\circ} \mathrm{C}, 6 \mathrm{~min}, 1 \% \mathrm{H}_{2} \mathrm{SO}_{4}\right)$. In conclusion, it can be said

300 that microwave pretreatment catalyzed by dilute sulfuric acid led to the recovery of $87 \%$

301 of the sugars contained in BSG (49 $\mathrm{g}$ of sugars from $100 \mathrm{~g}$ of untreated BSG). This

302 overall sugar recovery was higher than those previously reported for this raw material

303 after pretreatment with $\mathrm{H}_{3} \mathrm{PO}_{4}, 78 \%$ [32], or $\mathrm{HCl}$ plus $\mathrm{HNO}_{3}, 72 \%$ [38].

304 
305

306

307

308

309

310

311

312

313

314

315

316

317

318

\subsection{Microwave pretreatment assisted dilute sulfuric acid: optimization of operating} conditions

As previously explained, this work aims to recover sugars from both cellulose and hemicellulose in BSG through a microwave assisted dilute sulfuric acid pretreatment. In addition, inhibitory compounds should be as low as possible so as not to interfere in the $\mathrm{ABE}$ fermentation. Thus, in order to optimize the pretreatment, the responses chosen were the hemicellulosic sugar recovery in the liquid fraction $\left(\mathrm{HSR}_{\mathrm{L}}\right)$ and the glucose recovery in enzymatic hydrolysis (referred to untreated BSG), which were maximized simultaneously, as well as the total inhibitor concentration in the liquid fraction, which was minimized at the same time. The optimization was carried out using a method known as the desirability function, which allows different responses to be simultaneously optimized [39]. Polynomial equations of second order (Eqs. 2, 3 and 4) were proposed in order to calculate the responses (HSRL, EH glucose recovery and total inhibitor concentration in the liquid fraction):

$$
\mathrm{HSR}_{L}=80.87+9.79 \mathrm{~T}+1.74 \mathrm{t}+5.31 \mathrm{C}-5.35 \mathrm{Tt}-7.08 \mathrm{~T} \mathrm{C}-16.19 \mathrm{~T}^{2}-4.36 \mathrm{C}^{2}
$$

$$
\text { EH glucose recovery }=68.36+9.37 \mathrm{~T}+1.91 \mathrm{t}+2.48 \mathrm{C}-6 \mathrm{~T} \mathrm{t}-8.35 \mathrm{~T}^{2}-4.62 \mathrm{C}^{2}
$$

Total inhibitor in liquid fraction $=2.34+2.40 \mathrm{~T}+0.42 \mathrm{t}+0.50 \mathrm{C}-0.33 \mathrm{Tt}+0.74 \mathrm{~T} \mathrm{C}+0.71 \mathrm{tC}+0.68 \mathrm{~T}^{2}-0.22 \mathrm{C}^{2}$

319 where $\mathrm{T}$ is the temperature $\left({ }^{\circ} \mathrm{C}\right), \mathrm{t}$ is the time (min) and $\mathrm{C}$ is the sulfuric acid concentration $(\% \mathrm{w} / \mathrm{v})$.

The variance analyses (ANOVA) for $\mathrm{HSR}_{\mathrm{L}}, \mathrm{EH}$ glucose recovery and total inhibitor concentration in the liquid fraction are summarized in Supplemental Table 1S. As can

323 be seen, the three models were predictive, as suggested by their values of $\mathrm{R}^{2}$ and 324 adjusted $\mathrm{R}^{2}$ and the confidence level $(95 \%, \mathrm{p}<0.05)$.

325 Concerning the $\mathrm{HSR}_{\mathrm{L}}$ response (Eq. 2), the three factors (temperature, time and acid 326 concentration) exerted a positive effect, the influence of the temperature being higher 
327 than that of the acid concentration and time. The combined effect of temperature and 328 time, or temperature and acid concentration, lead to a decrease in the HSR $\mathrm{L}_{\mathrm{L}}$, probably 329 due to a lack of hemicellulose solubilization or sugar degradation at very soft or severe 330 pretreatment conditions, respectively. This behavior can be observed in Fig. 1(a,b),

331 which depicts the response surface showing the influence of temperature and time (Fig.

332 1a), or of temperature and acid concentration (Fig. 1b) on the $\mathrm{HSR}_{\mathrm{L}}$. In this way, as can 333 be observed, it is in the area close to the central point $\left(145^{\circ} \mathrm{C}, 6 \mathrm{~min}, 1 \% \mathrm{H}_{2} \mathrm{SO}_{4}\right)$ where 334 the highest $\mathrm{HSR}_{\mathrm{L}}$ was achieved.

335 Regarding glucose recovery, the three factors have a positive effect (Eq. 3).

336 However, in this case, the temperature factor has a much higher influence than time or

337 sulfuric acid concentration. What is more, there is a considerable negative interaction

338 between temperature and time. Fig. 1(c,d) plots the 3D response surface for glucose

339 recovery in enzymatic hydrolysis, considering temperature and time (Fig. 1c), or

340 temperature and sulfuric acid concentration (Fig. 1d). The glucose recovery increases as

341 the temperature and time rise, until a certain level (near the central point conditions) is

342 reached, where it begins to decrease (Fig. 1c). This is due to the negative interaction

343 between temperature and time, as explained above. On the other hand, the interaction

344 between the temperature and sulfuric acid concentration was insignificant, as can be 345 appreciated in Eq. (3) and Fig. 1d.

346 Considering the total inhibitor concentration in the liquid fraction (Eq. 4), all the 347 variables exerted positive effects, including the interactions between temperature and 348 sulfuric acid concentration and between time and acid concentration, the influence of 349 temperature being slightly higher. On the contrary, a very slight negative interaction can 350 be appreciated between temperature and time. Therefore, the total inhibitor 
351 concentration increases when temperature and time (Fig. 1e), or temperature and

352 sulfuric acid concentration (Fig. 1f), increase simultaneously.

353 As a result, $147^{\circ} \mathrm{C}, 2 \mathrm{~min}$ and $1.26 \%(\mathrm{w} / \mathrm{v}) \mathrm{H}_{2} \mathrm{SO}_{4}$ were the optimal conditions which

354 the model predicted. Under these optimal pretreatment conditions, the best results found

355 by the model were $81.6 \%, 67.8 \%$ and $2.0 \mathrm{~g} / \mathrm{L}$ for the $\mathrm{HSR}_{\mathrm{L}}$, recovery of glucose in

356 enzymatic hydrolysates (referred to non-pretreated BSG) and total concentration of

357 inhibitors in the liquid fraction, respectively. In order to confirm the optimization

358 results, an experimental run was performed under the optimal conditions for

359 pretreatment $(\mathrm{CSF}=1.26)($ Table 6$)$. As was expected, a cellulose-enriched solid was

360 obtained, as well as a liquid fraction with $33.5 \mathrm{~g} / \mathrm{L}$ of monomeric sugars, which is

361 equivalent to $81 \%$ hemicellulosic sugar recovery. Additionally, inhibitory compounds in

362 the liquid fraction were about $2.4 \mathrm{~g} / \mathrm{L}$, mainly due to the presence of acetic acid, furfural

363 and phenolic compounds. The pretreated solid fraction resulting from the pretreatment

364 conducted under optimal conditions was enzymatically hydrolyzed, yielding a glucose

365 recovery (referred to untreated BSG) of 64.7\%. Thus, in general, a good agreement was

366 found between the predicted and the observed values $\left(\mathrm{HSR}_{\mathrm{L}} 81.6 \mathrm{vs} 81 \%\right.$; EH glucose

367 recovery 67.8 vs $64.7 \%$; total inhibitor concentration, 2.0 vs $2.4 \mathrm{~g} / \mathrm{L}$ ). Under these

368 optimal conditions, an overall sugar recovery of $85.3 \%$ was achieved (47.3 $\mathrm{g}$ of sugars

369 from $100 \mathrm{~g}$ of BSG), considering sugars in the liquid fraction and the glucose and

370 xylose obtained from the pretreated solid by enzymatic hydrolysis.

371

372

\subsection{Use of the whole slurry in enzymatic hydrolysis}

373 The use of the whole slurry obtained after the lignocellulosic biomass pretreatment,

374 without solid-liquid separation, is very interesting as it leads to a unique hydrolysate

375 which contains both cellulosic and hemicellulosic sugars, and these can be fermented 
376

377

378

379

380

381

382

383

384

385

386

387

388

389

390

391

392

393

394

395

396

397

398

399

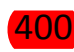

together. Thus, in order to analyze the effect of the use of the slurries on the

effectiveness of the enzymatic hydrolysis stage, the whole slurry obtained after the pretreatment of BSG at two solid loadings (10 and 15\% w/v) under optimal conditions

$\left(147^{\circ} \mathrm{C}, 2 \mathrm{~min}\right.$ and $\left.1.26 \% \mathrm{w} / \mathrm{v} \mathrm{H}_{2} \mathrm{SO}_{4}\right)$ was subjected to enzymatic saccharification.

Higher sugar concentrations can be found in the hydrolysates resulting from higher

solid concentrations in the pretreatment, which could increase the butanol concentration in the further fermentation step. This fact is profitable for the downstream stage, as it is necessary to obtain butanol with a purity higher than $99 \%$ for industrial uses [40].

Considering the sugars from the enzymatic hydrolysis and the prehydrolysate, the total sugar concentrations in the whole slurries were 47.6 and $73.9 \mathrm{~g} / \mathrm{L}$ at 10 and $15 \%$ (w/v) of solid load in pretreatment, respectively, under optimal conditions (Table 7).

\subsection{ABE fermentation of the slurry enzymatic hydrolysate}

The hydrolysates corresponding to the enzymatic hydrolysis of the whole slurries obtained at $10 \%$ and $15 \%$ solid load in the pretreatment (slurry enzymatic hydrolysates, SEH_10\% and SEH_15\%,respectively), were fermented with C. beijerinckii. However, none of these hydrolysates produced butanol. This was probably due to the presence of phenolic compounds and furfural. According to Klinke et al. [41], a highly negative synergistic effect of furfural and phenols can take place.

Thereby, both SEH_10\% and SEH_15\% were detoxified with activated charcoal (SEH-ACD) or ion-exchange resins, SEH-RD (Lewatit S4528), to decrease the inhibitor compounds. Table 7 shows the carbohydrate and inhibitor concentrations measured in the different SEH before and after detoxification. Regarding the detoxification by activated charcoal, which is a process that is highly effective, economical and proficient 
401 percentages (Table 7) in both SEH_10\%-ACD and SEH_15\%-ACD (100 and 70-83\%,

402 respectively), as was also reported by other authors [33,43,44], It is worth mentioning

403 that, although only a $2 \%$ activated charcoal load was necessary for the SEH_10\%, a

404 slightly higher charcoal load (5\%) was employed in the case of SEH_15\%, since this

405 hydrolysate contained higher inhibitor concentrations.

406 Concerning the detoxification with ion-exchange resins (Table 7), this method also

407 shows a high capacity for removing furfural and phenols (100 and 40-61\%,

408 respectively) in both $\mathrm{SEH} \_10 \%-\mathrm{RD}$ and $\mathrm{SEH} \_15 \%-\mathrm{RD}$, its effect being negligible for

409 the other inhibitor compounds, as was previously reported $[45,46]$. In the case of

410 SEH_10\%, a resin concentration of $2 \%$ was necessary, whereas the resin concentration

411 has to be increased to $10 \%$ for SEH_15\%.

412 Regarding ABE fermentation, Fig. 2 shows the initial and final monosaccharide

413 concentrations, as well as the butanol and ABE concentrations obtained for SEH_10\%-

414 ACD and SEH_15\%-ACD (Fig. 2a), and for SEH_10\%-RD and SEH_15\%-RD (Fig.

415 2b). In this way, as can be seen, in the case of SEH_10\%, 8.2 and $8.0 \mathrm{~g} / \mathrm{L}$ butanol were

416 obtained when the hydrolysate was detoxified with activated charcoal (Fig. 2a) or ion-

417 exchange resins (Fig. 2b), respectively, which resulted in high butanol yields (0.26 and

$4180.24 \mathrm{~g} / \mathrm{g}$ sugars consumed, respectively) (Table 8). It is worth noting that only $2 \%(\mathrm{w} / \mathrm{v})$

419 activated charcoal or resin-liquid was employed in this case. ABE concentrations

420 achieved were also high from both SEH_10\%-ACD and SEH_10\%-RD (11.8 and 12.0

$421 \mathrm{~g} / \mathrm{L}$ ABE, respectively), which corresponds to $\mathrm{ABE}$ yields of 0.37 and $0.35 \mathrm{~g} / \mathrm{g}$ sugars

422 consumed, respectively, and ABE productivities of 0.285 and $0.291 \mathrm{~g} / \mathrm{L} \cdot \mathrm{h}$, respectively.

423 Almost all sugars were used by $C$. beijerinckii in both SEH_10\%-ACD and SEH_10\%-

424 RD (sugar uptake $=97-97.9 \%$, Table 8). 
Concerning SEH_15\%, as can be seen in Fig. 2, butanol concentrations as high as 42610.8 and $11.0 \mathrm{~g} / \mathrm{L}$ were achieved for $\mathrm{SEH} \_15 \%-\mathrm{ACD}$ and $\mathrm{SEH} \_15 \%-\mathrm{RD}$, respectively 427 (16.0 and $16.9 \mathrm{~g} / \mathrm{L} \mathrm{ABE}$, respectively). Therefore, it can be said that the use of more 428 concentrated hydrolysates in sugars allowed fermentation broths to be obtained with 429 higher butanol and ABE concentrations. On the other hand (Table 8), although 430 fermentation with SEH_15\% also resulted in high yields of butanol $(0.21$ and $0.22 \mathrm{~g} / \mathrm{g}$ 431 for SEH_15\%-ACD and SEH_15\%-RD, respectively) and ABE (0.32 and $0.33 \mathrm{~g} / \mathrm{g}$ for 432 SEH_15\%-ACD and SEH_15\%-RD, respectively), these yields were slightly lower than 433 those obtained for SEH_10\%. On the other hand, as can be observed in Figure 2, in 434 SEH_15\%, the sugars were not completely consumed, with 7.4 and $5.1 \mathrm{~g} / \mathrm{L}$ of 435 unconsumed total sugars remaining at the end of fermentation for SEH_15\%-ACD and 436 SEH_15\%-RD, respectively. According to Gu et al. [47], the presence of unconsumed 437 sugars at the end of the ABE fermentation is due to final product inhibition (butanol). A 438 model medium with the same concentration of sugars present in SEH_15\% (58 g/L), but 439 without the presence of inhibitors was also fermented (data not shown), resulting in 440 similar butanol and ABE concentrations (10 and $14.3 \mathrm{~g} / \mathrm{L}$, respectively), butanol and 441 ABE yields (0.20 and $0.28 \mathrm{~g} / \mathrm{g}$ sugars consumed, respectively) and $7.9 \mathrm{~g} / \mathrm{L}$ unconsumed 442 sugar remaining at the end of the fermentation. Therefore, recovery processes which 443 allow butanol and ABE solvents to be recovered from the fermentation broth should be 444 used, such as gas stripping separation, liquid-liquid extraction, adsorption or 445 pervaporation techniques [48].

446 On the other hand, as Table 8 shows, butyric acid concentrations at the end of 447 fermentation were low $(<0.3 \mathrm{~g} / \mathrm{L})$, which is adequate, since butyric acid is generated 448 during the acidogenic phase and later consumed during the solventogenic phase to 449 produce butanol [5]. 
450 Experimental results compare favorably with those reported by Nguyen et al. [49],

451 who fermented with $C$. acetobutylicum the non-detoxified whole slurry of green

452 macroalgae Enteromorpha intestinalis, pretreated by sulfuric acid pretreatment $\left(121^{\circ} \mathrm{C}\right.$,

$45360 \mathrm{~min}, 270 \mathrm{mM} \mathrm{H}_{2} \mathrm{SO}_{4}$ ), obtaining $8.5 \mathrm{~g} / \mathrm{L} \mathrm{ABE}$. Nimbalkar et al. [50] reached butanol

454 and ABE concentrations of only 4.43 and $6.69 \mathrm{~g} / \mathrm{L}$, respectively, after ABE

455 fermentation with C. acetobutylicum of hydrolysates obtained after sulfuric acid

456 pretreatment $\left(121^{\circ} \mathrm{C}, 15 \mathrm{~min}, 1.5 \% \mathrm{H}_{2} \mathrm{SO}_{4}\right)$ of sugarcane industry waste. Microwave

457 assisted hydrothermal pretreatment $\left(192.7^{\circ} \mathrm{C}\right.$ and $\left.5.4 \mathrm{~min}\right)$ of $\mathrm{BSG}$ [23] led to $8.3 \mathrm{~g} / \mathrm{L}$

458 butanol and a butanol yield of $0.26 \mathrm{~g} / \mathrm{g}$ from the fermentation of the enzymatic

459 hydrolysate of the pretreated solid. Therefore, the process based on microwave assisted

460 dilute sulfuric acid pretreatment developed in this work allows a lower temperature and

461 process time to be used $\left(147^{\circ} \mathrm{C}\right.$ and $2 \mathrm{~min}$, respectively) in the presence of dilute

462 sulfuric acid $\left(1.26 \% \mathrm{H}_{2} \mathrm{SO}_{4}\right)$ for the production of biobutanol from pentoses and

463 hexoses in a single bioreactor.

464

465

466

\subsection{Overall process material balance}

The material balance of the overall process for ABE production from BSG with $C$.

467 beijerinckii, regarding the process configuration developed in this work, is shown in

468 Fig. 3. BSG was submitted to an acid pretreatment under optimal conditions $\left(147^{\circ} \mathrm{C}, 2\right.$

$469 \min , 1.26 \% \mathrm{H}_{2} \mathrm{SO}_{4}$ ) at 10 and $15 \% \mathrm{w} / \mathrm{v}$ solid load, resulting in a slurry (with 4.8 and

$4707.9 \%$ of pretreated solid concentration), which was enzymatically hydrolyzed and

471 fermented with $C$. beijerinckii after detoxification by activated charcoal. In this way,

472 regarding the pretreatment at a solid load of $10 \%(\mathrm{w} / \mathrm{v})$, a total production of $113 \mathrm{~g}$

473 butanol/kg BSG (dry matter) and $162 \mathrm{~g} \mathrm{ABE} / \mathrm{kg} \mathrm{BSG}$ (dry matter) can be obtained (Fig.

474 3a). Nevertheless, $91 \mathrm{~g}$ butanol/kg BSG and $138 \mathrm{~g} \mathrm{ABE} / \mathrm{kg}$ BSG were achieved when 
475 the pretreatment solid load used in the pretreatment was increased to $15 \%(\mathrm{w} / \mathrm{v})$ (Fig.

$4763 \mathrm{~b}$ ). Although the use of a higher solid load in the pretreatment resulted in lower global

477 butanol and ABE yields, the final concentration of the ABE solution was $36 \%$ higher,

478 which allows the downstream process to be more feasible economically. The

479 consumption of water and sulfuric acid was also lower.

480 Plaza et al. [26] reported a lower butanol and ABE production (75 g butanol/kg BSG and $95 \mathrm{~g} \mathrm{ABE} / \mathrm{kg} \mathrm{BSG}$, respectively) after dilute sulfuric acid pretreatment and fermentation with $C$. beijerinckii. Fernández-Delgado et al. [34] achieved a much lower butanol and ABE production after pretreating BSG with $\mathrm{NaOH}$ (44 g butanol/kg BSG and $54 \mathrm{~g} \mathrm{ABE} / \mathrm{kg} \mathrm{BSG}$ ) or $\mathrm{H}_{2} \mathrm{O}_{2}$ (45 g butanol/kg BSG and $56 \mathrm{~g} \mathrm{ABE/kg} \mathrm{BSG).}$

Therefore, it is worth mentioning that the microwave assisted dilute sulfuric acid pretreatment process carried out in this work allowed the combined valorization of cellulosic and hemicellulosic sugars, through their biotransformation to butanol.

\section{Conclusions}

This work shows that microwave pretreatment assisted by dilute sulfuric acid is an interesting choice to recover all sugars contained in BSG, the optimal conditions being $147{ }^{\circ} \mathrm{C}, 2$ min and $1.26 \% \mathrm{H}_{2} \mathrm{SO}_{4}$ at $10 \%$ biomass loading. In addition, the complete valorization of cellulosic and hemicellulosic sugars contained in BSG is possible by fermentation to biobutanol of the highly concentrated slurry enzymatic hydrolysates, using a single fermenter. Thus, when a biomass load of $15 \%(\mathrm{w} / \mathrm{v})$ was used in the pretreatment, this process configuration allowed a butanol concentration as high as 11 $\mathrm{g} / \mathrm{L}$ to be reached, yielding $91 \mathrm{~kg}$ butanol/t BSG and $138 \mathrm{~kg} \mathrm{ABE/t} \mathrm{BSG.} \mathrm{Future} \mathrm{work}$ will focus on the optimization of fermentation system, such as gas stripping separation 
499 technique, which allow butanol and ABE solvents to be recovered from the

500 fermentation broth.

501

502 Conflict of interest

503 Declarations of interest: none

504

505 Acknowledgements

506 The authors would like to thanks the economic support of the Regional Government of

507 Castilla y León and EU-FEDER (VA010P17, UIC 129). The support from the project

508 CLU 2017-09 is also acknowledged.

509

510 Appendix A. Supplementary data

511 Supplementary data associated with this article can be found in the online version.

512

513 REFERENCES

514 [1] Directive (EU) 2015/1513 of the European Parliament and of the Council of 9 September 2015, ., (2015). doi:10.2903/j.efsa.2013.3381.

[2] P. Wang, Y.M. Chen, Y. Wang, Y.Y. Lee, W. Zong, S. Taylor, T. McDonald, Y. Wang, Towards comprehensive lignocellulosic biomass utilization for bioenergy production: Efficient biobutanol production from acetic acid pretreated switchgrass with Clostridium saccharoperbutylacetonicum N1-4, Appl. Energy. 236 (2019) 551-559. doi:10.1016/j.apenergy.2018.12.011.

[3] G. Qi, L. Xiong, H. Li, Q. Huang, M. Luo, L. Tian, X. Chen, C. Huang, X. Chen, 522 Hydrotropic pretreatment on wheat straw for efficient biobutanol production, 523 Biomass and Bioenergy. 122 (2019) 76-83. doi:10.1016/j.biombioe.2019.01.039. 
524 [4] P. Dürre, Fermentative production of butanol - the academic perspective, Curr.

525

526

527

528

529

530

531

532

533

534

535

536

537

538

539

540

541

542

543

544

545

546

547

548

Opin. Biotechnol. 22 (2011) 331-336. doi:10.1016/j.copbio.2011.04.010.

[5] B. Satari, K. Karimi, R. Kumar, Cellulose solvent-based pretreatment for enhanced second-generation biofuel production: a review, Sustain. Energy Fuels. 3 (2019) 11-62. doi:10.1039/C8SE00287H.

[6] S.I. Mussatto, I.C. Roberto, Chemical characterization and liberation of pentose sugars from brewer's spent grain, J. Chem. Technol. Biotechnol. 81 (2006) 268274. doi:10.1002/jctb.1374.

[7] A. Brosowski, D. Thrän, U. Mantau, B. Mahro, G. Erdmann, P. Adler, W.

Stinner, G. Reinhold, T. Hering, C. Blanke, A review of biomass potential and current utilisation - Status quo for 93 biogenic wastes and residues in Germany, Biomass and Bioenergy. 95 (2016) 257-272. doi:10.1016/j.biombioe.2016.10.017.

[8] FAOSTAT, Food and Agriculture Organization of the United Nations, (2019). http://faostat3.fao.org/ (accessed February 5, 2019).

[9] K.M. Lynch, E.J. Steffen, E.K. Arendt, Brewers' spent grain: a review with an emphasis on food and health, J. Inst. Brew. 122 (2016) 553-568. doi:10.1002/jib.363.

[10] H. Zhang, N. Li, X. Pan, S. Wu, J. Xie, Oxidative conversion of glucose to gluconic acid by iron(III) chloride in water under mild conditions, Green Chem. 18 (2016) 2308-2312. doi:10.1039/c5gc02614h.

[11] K. Rajendran, E. Drielak, V. Sudarshan Varma, S. Muthusamy, G. Kumar, Updates on the pretreatment of lignocellulosic feedstocks for bioenergy production-a review, Biomass Convers. Biorefinery. 8 (2018) 471-483. doi:10.1007/s13399-017-0269-3. 
549 [12] B.J. Alvarez-Chavez, S. Godbout, J.H. Palacios-Rios, É. Le Roux, V. Raghavan, 550 Physical, chemical, thermal and biological pre-treatment technologies in fast 551 pyrolysis to maximize bio-oil quality: A critical review, Biomass and Bioenergy. $552 \quad 128(2019)$ 105333. doi:10.1016/j.biombioe.2019.105333.

553 [13] Y. Zheng, J. Zhao, F. Xu, Y. Li, Pretreatment of lignocellulosic biomass for 554 enhanced biogas production, Prog. Energy Combust. Sci. 42 (2014) 35-53. $555 \quad$ doi:10.1016/j.pecs.2014.01.001.

556 [14] W.-H. Chen, Y.-J. Tu, H.-K. Sheen, Disruption of sugarcane bagasse 557 lignocellulosic structure by means of dilute sulfuric acid pretreatment with 558 microwave-assisted heating, Appl. Energy. 88 (2011) 2726-2734.

559 doi:10.1016/J.APENERGY.2011.02.027.

560 [15] H. Rasmussen, H.R. Sørensen, A.S. Meyer, Formation of degradation compounds 561 from lignocellulosic biomass in the biorefinery: sugar reaction mechanisms, $562 \quad$ Carbohydr. Res. 385 (2014) 45-57. doi:10.1016/j.carres.2013.08.029.

563 [16] A. Aguilar-Reynosa, A. Romaní, R. Ma. Rodríguez-Jasso, C.N. Aguilar, G. 564 Garrote, H.A. Ruiz, Microwave heating processing as alternative of pretreatment 565 in second-generation biorefinery: An overview, Energy Convers. Manag. 136 566 (2017) 50-65. doi:10.1016/j.enconman.2017.01.004.

567 [17] S.S. Hassan, G.A. Williams, A.K. Jaiswal, Emerging technologies for the 568 pretreatment of lignocellulosic biomass, Bioresour. Technol. 262 (2018) 310569 318. doi:10.1016/j.biortech.2018.04.099.

570 [18] O. Merino-Pérez, R. Martínez-Palou, J. Labidi, R. Luque, Microwave-assisted 571 pretreatment of lignocellulosic biomass to produce biofuels and value-added 572 products, in: Z. Fang, R.L. Smith,, X. Qi (Eds.), Prod. Biofuels Chem. with 573 Microw., Springer Netherlands, New York, 2015: pp. 197-224. doi:10.1007/978- 
575 [19] D. Mikulski, G. Kłosowski, A. Menka, B. Koim-Puchowska, Microwave-assisted pretreatment of maize distillery stillage with the use of dilute sulfuric acid in the production of cellulosic ethanol, Bioresour. Technol. 278 (2019) 318-328. doi:10.1016/j.biortech.2019.01.068.

[20] Y. Yin, J. Wang, Pretreatment of macroalgal Laminaria japonica by combined microwave-acid method for biohydrogen production, Bioresour. Technol. 268 (2018) 52-59. doi:10.1016/j.biortech.2018.07.126.

[21] A. Xia, J. Cheng, W. Song, C. Yu, J. Zhou, K. Cen, Enhancing enzymatic saccharification of water hyacinth through microwave heating with dilute acid pretreatment for biomass energy utilization, Energy. 61 (2013) 158-166. doi:10.1016/j.energy.2013.09.019.

[22] C.C. Geddes, M.T. Mullinnix, I.U. Nieves, J.J. Peterson, R.W. Hoffman, S.W. York, L.P. Yomano, E.N. Miller, K.T. Shanmugam, L.O. Ingram, Simplified process for ethanol production from sugarcane bagasse using hydrolysateresistant Escherichia coli strain MM160, Bioresour. Technol. 102 (2011) 27022711. doi:10.1016/j.biortech.2010.10.143.

[23] J.C. López-Linares, M.. García-Cubero, S. Lucas, G. González-Benito, M. Coca, Microwave assisted hydrothermal as greener pretreatment of brewer's spent grains for biobutanol production, Chem. Eng. J. 368 (2019) 1045-1055. doi:10.1016/J.CEJ.2019.03.032.

[24] J.C. López-Linares, M.T. García-Cubero, S. Lucas, G. González-Benito, M. Coca, Microwave assisted sulfuric acid pretreatment as suitable alternative for sugar recovery from brewer's spent grain, in: Á.G. S.L.L (Ed.), IWBLCM 2019, Córdoba (España), 2019: pp. 136-140. 
599 [25] J.J. MacAskill, I.D. Suckling, J.A. Lloyd, M. Manley-Harris, Unravelling the 600 effect of pretreatment severity on the balance of cellulose accessibility and 601 substrate composition on enzymatic digestibility of steam-pretreated softwood, Biomass and Bioenergy. 109 (2018) 284-290.

603 doi:10.1016/j.biombioe.2017.12.018.

604

[26] P.E. Plaza, L.J. Gallego-Morales, M. Peñuela-Vásquez, S. Lucas, M.T. García605 Cubero, M. Coca, Biobutanol production from brewer's spent grain hydrolysates 606 607 608 609 610 611 by Clostridium beijerinckii, Bioresour. Technol. 244 (2017) 166-174. doi:10.1016/j.biortech.2017.07.139.

[27] A. Sluiter, B. Hames, R. Ruiz, C. Scarlata, J. Sluiter, D. Templeton, Determination of ash in biomass. National Renewable Energy Laboratory, Golden, Color. (Jan, Rep. No. TP-510-42622). (2008).

[28] A. Sluiter, B. Hames, R. Ruiz, C. Scarlata, J. Sluiter, D. Templeton, Determination of structural carbohydrates and lignin in biomass. National Renewable Energy Laboratory, Golden, Color. (Jan, Rep. No. TP-510-42618). (2011).

[29] V.L. Singleton, S.A. Rossi, Colorimetric of total phenolics with phosphomolibicphosphotungstic acid reagents, J. Enol. Vitic. 16 (1965) 144-158. doi:10.12691/ijebb-2-1-5.

[30] I. Ballesteros, M. Ballesteros, C. Cara, F. Sáez, E. Castro, P. Manzanares, M.J. Negro, J.M. Oliva, Effect of water extraction on sugars recovery from steam exploded olive tree pruning, Bioresour. Technol. 102 (2011) 6611-6616. doi:10.1016/j.biortech.2011.03.077.

[31] H. Jørgensen, M. Pinelo, Enzyme recycling in lignocellulosic biorefineries, Biofuels, Bioprod. Biorefining. 11 (2017) 150-167. doi:10.1002/bbb.1724. 
624 [32] J.A. Rojas-Chamorro, C. Cara, I. Romero, E. Ruiz, J.M. Romero-García, S.I.

625 Mussatto, E. Castro, Ethanol production from brewers' spent grain pretreated by

626 dilute phosphoric acid, Energy \& Fuels. 32 (2018) 5226-5233.

627 doi:10.1021/acs.energyfuels.8b00343.

628 [33] D.I. Díaz-Blanco, J.R. de La Cruz, J.C. López-Linares, T.K. Morales-Martínez,

629 E. Ruiz, L.J. Rios-González, I. Romero, E. Castro, Optimization of dilute acid

630 pretreatment of Agave lechuguilla and ethanol production by co-fermentation

631 with Escherichia coli MM160, Ind. Crops Prod. 114 (2018) 154-163.

632 doi:10.1016/j.indcrop.2018.01.074.

633 [34] M. Fernández-Delgado, P.E. Plaza, M. Coca, M.T. García-Cubero, G. González-

634 Benito, S. Lucas, Comparison of mild alkaline and oxidative pretreatment

635 methods for biobutanol production from brewer's spent grains, Ind. Crops Prod.

636130 (2019) 409-419. doi:10.1016/j.indcrop.2018.12.087.

637 [35] H. Patel, J. Divecha, A. Shah, Microwave assisted alkali treated wheat straw as a

638 substrate for co-production of (hemi)cellulolytic enzymes and development of

639 balanced enzyme cocktail for its enhanced saccharification, J. Taiwan Inst.

$640 \quad$ Chem. Eng. 71 (2017) 298-306. doi:10.1016/j.jtice.2016.12.032.

641 [36] N. Yu, L. Tan, Z.-Y. Sun, Y.-Q. Tang, K. Kida, Production of bio-ethanol by

642 integrating microwave-assisted dilute sulfuric acid pretreated sugarcane bagasse

643 slurry with molasses, Appl. Biochem. Biotechnol. 185 (2018) 191-206.

644 doi:10.1007/s12010-017-2651-9.

645 [37] K. Karimi, M.J. Taherzadeh, A critical review of analytical methods in

646

pretreatment of lignocelluloses: Composition, imaging, and crystallinity,

647

Bioresour. Technol. 200 (2016) 1008-1018. doi:10.1016/j.biortech.2015.11.022.

648

[38] N.S. Caetano, R.F. Moura, S. Meireles, A.M. Mendes, T.M. Mata, Bioethanol 
650

651

652

653

654

655

656

657

658

659

660

661

662

663

664

665

666

667

668

669

670

671

672

673

from brewer's spent grains: acid pretreatment optimization, Chem. Eng. Trans. 35 (2013) 1021-1026. doi:10.3303/CET1335170.

[39] L. Mesa, Y. Martínez, E. Barrio, E. González, Desirability function for optimization of Dilute Acid pretreatment of sugarcane straw for ethanol production and preliminary economic analysis based in three fermentation configurations, Appl. Energy. 198 (2017) 299-311. doi:10.1016/j.apenergy.2017.03.018.

[40] D. Cai, H. Chen, C. Chen, S. Hu, Y. Wang, Z. Chang, Q. Miao, P. Qin, Z. Wang, J. Wang, T. Tan, Gas stripping-pervaporation hybrid process for energy-saving product recovery from acetone-butanol-ethanol $(\mathrm{ABE})$ fermentation broth, Chem. Eng. J. 287 (2016) 1-10. doi:10.1016/j.cej.2015.11.024.

[41] H.B. Klinke, A.B. Thomsen, B.K. Ahring, Inhibition of ethanol-producing yeast and bacteria by degradation products produced during pre-treatment of biomass, Appl. Microbiol. Biotechnol. 66 (2004) 10-26. doi:10.1007/s00253-004-1642-2.

[42] L. Canilha, W. Carvalho, M. das G.A. Felipe, J.B. de A. Silva, Xylitol production from wheat straw hemicellulosic hydrolysate: hydrolysate detoxification and carbon source used for inoculum preparation, Brazilian J. Microbiol. 39 (2008) 333-336. doi:10.1590/S1517-83822008000200025.

[43] P.L. Brito, C.M. de Azevedo Ferreira, A.F.F. Silva, L. de A. Pantoja, D.L. Nelson, A.S. dos Santos, Hydrolysis, detoxification and alcoholic fermentation of hemicellulose fraction from palm press fiber, Waste and Biomass Valorization. 9 (2018) 957-968. doi:10.1007/s12649-017-9882-4.

[44] T.L. de Albuquerque, S.D.L. Gomes, J.E. Marques Jr., I.J. da Silva Jr., M.V.P. Rocha, Xylitol production from cashew apple bagasse by Kluyveromyces marxianus CCA510, Catal. Today. 255 (2015) 33-40. 

676
675 [45] J.C. López-Linares, I. Romero, C. Cara, E. Castro, Bioconversion of rapeseed straw: enzymatic hydrolysis of whole slurry and cofermentation by an ethanologenic Escherichia coli, Energy \& Fuels. 30 (2016) 9532-9539. doi:10.1021/acs.energyfuels.6b02308.

[46] J. Li, S. Shi, M. Tu, B. Via, F.F. Sun, S. Adhikari, Detoxification of organosolvpretreated pine prehydrolysates with anion resin and cysteine for butanol fermentation, Appl. Biochem. Biotechnol. 186 (2018) 662-680. doi:10.1007/s12010-018-2769-4.

[47] Y. Gu, Y. Jiang, H. Wu, X. Liu, Z. Li, J. Li, H. Xiao, Z. Shen, H. Dong, Y. Yang, Y. Li, W. Jiang, S. Yang, Economical challenges to microbial producers of butanol: Feedstock, butanol ratio and titer, Biotechnol. J. 6 (2011) 1348-1357. doi:10.1002/biot.201100046.

[48] C. Xue, J. Zhao, L. Chen, S.-T. Yang, F. Bai, Recent advances and state-of-theart strategies in strain and process engineering for biobutanol production by Clostridium acetobutylicum, Biotechnol. Adv. 35 (2017) 310-322. doi:10.1016/j.biotechadv.2017.01.007.

[49] T.H. Nguyen, I.Y. Sunwoo, C.H. Ra, G.-T. Jeong, S.-K. Kim, Acetone, butanol, and ethanol production from the green seaweed Enteromorpha intestinalis via the separate hydrolysis and fermentation, Bioprocess Biosyst. Eng. (2018). doi:10.1007/s00449-018-2045-6.

[50] P.R. Nimbalkar, M.A. Khedkar, S.G. Gaikwad, P. V. Chavan, S.B. Bankar, New insight into sugarcane industry waste utilization (press mud) for cleaner biobutanol production by using C. acetobutylicum NRRL B-527, Appl. Biochem. Biotechnol. 183 (2017) 1008-1025. doi:10.1007/s12010-017-2479-3. 
1

2

3

4

5

9

10

11

12

13

14

15

16

17

18

19

20

21

22

23

24

25

26

27

28

29

30

31

32

33

34

35

36

37

38

39

40

41

42

43

44

45

46

47

48

49

50

51

52

53

54

55

56

57

58

59

60

61

62

63

64

65 


\section{TABLES}

Table 1. Microwave pretreatment assisted by dilute sulfuric acid pretreatment of BSG.

Experimental design (coded and real factors) and Combined Severity Factor (CSF).

\begin{tabular}{|c|c|c|c|c|c|c|c|}
\hline \multirow[t]{2}{*}{ Run } & \multicolumn{2}{|c|}{ Temperature $\left({ }^{\circ} \mathrm{C}\right)$} & \multicolumn{2}{|c|}{ Time (min) } & \multicolumn{2}{|c|}{$\begin{array}{c}\mathrm{H}_{2} \mathrm{SO}_{4} \text { conc. } \\
(\%)\end{array}$} & \multirow[t]{2}{*}{$\mathrm{CSF}$} \\
\hline & Coded & Real & Coded & Real & Coded & Real & \\
\hline 1 & 0 & 145 & 0 & 6 & -1.41 & 0.16 & 0.74 \\
\hline 2 & +1 & 170 & +1 & 10 & -1 & 0.50 & 2.19 \\
\hline 3 & 0 & 145 & +1.41 & 12.73 & 0 & 1 & 1.93 \\
\hline 4 & 0 & 145 & -1.41 & 0 & 0 & 1 & -0.70 \\
\hline 5 & 0 & 145 & 0 & 6 & 0 & 1 & 1.60 \\
\hline 6 & 0 & 145 & 0 & 6 & +1.41 & 1.84 & 1.84 \\
\hline 7 & -1 & 120 & +1 & 10 & -1 & 0.50 & 0.72 \\
\hline 8 & +1 & 170 & -1 & 2 & -1 & 0.50 & 1.49 \\
\hline 9 & -1.41 & 102.96 & 0 & 6 & 0 & 1 & 0.37 \\
\hline 10 & 0 & 145 & 0 & 6 & 0 & 1 & 1.60 \\
\hline 11 & -1 & 120 & +1 & 10 & +1 & 1.50 & 1.24 \\
\hline 12 & 0 & 145 & 0 & 6 & 0 & 1 & 1.60 \\
\hline 13 & -1 & 120 & -1 & 2 & +1 & 1.50 & 0.54 \\
\hline 14 & +1 & 170 & +1 & 10 & +1 & 1.50 & 2.71 \\
\hline 15 & -1 & 120 & -1 & 2 & -1 & 0.50 & 0.02 \\
\hline 16 & 0 & 145 & 0 & 6 & 0 & 1 & 1.60 \\
\hline 17 & 0 & 145 & 0 & 6 & 0 & 1 & 1.60 \\
\hline 18 & +1 & 170 & -1 & 2 & +1 & 1.50 & 2.01 \\
\hline 19 & +1.41 & 187.04 & 0 & 6 & 0 & 1 & 2.84 \\
\hline 20 & 0 & 145 & 0 & 6 & 0 & 1 & 1.60 \\
\hline
\end{tabular}


Table 2. Microwave pretreatment of BSG assisted by dilute sulfuric acid. Recovery of

total solids (\%), and composition of the solid fraction after pretreatment. Recovery (\%) of glucose $\left(\mathrm{GR}_{\mathrm{S}}\right)$ and hemicellulosic sugars $\left(\mathrm{HSR}_{\mathrm{S}}\right)$ in the solid fraction.

\begin{tabular}{cccccccc}
\hline Run & CSF & $\begin{array}{c}\text { Solid } \\
\text { Recovery } \\
(\%)\end{array}$ & $\begin{array}{c}\text { Cellulose } \\
(\mathrm{g} / 100 \mathrm{~g} \\
\text { pretreated } \\
\text { BSG })\end{array}$ & $\begin{array}{c}\text { Hemicellulose } \\
(\mathrm{g} / 100 \text { g pretreated } \\
\text { BSG })\end{array}$ & $\begin{array}{c}\text { Lignin } \\
(\mathrm{g} / 100 \text { g pretreated } \\
\text { BSG })\end{array}$ & $\begin{array}{c}\text { GRS } \\
(\%)\end{array}$ & $\begin{array}{c}\text { HSR } \\
(\%)\end{array}$ \\
\hline 1 & 0.74 & 59.29 & $21.61 \pm 0.67$ & $14.59 \pm 0.37$ & $36.32 \pm 0.18$ & 60.94 & 30.18 \\
2 & 2.19 & 42.74 & $33.11 \pm 0.26$ & $1.28 \pm 0.47$ & $46.09 \pm 0.33$ & 67.29 & 1.91 \\
3 & 1.93 & 40.74 & $33.73 \pm 0.81$ & $3.27 \pm 0.02$ & $44.70 \pm 0.13$ & 65.36 & 4.64 \\
4 & -0.70 & 47.08 & $30.24 \pm 0.56$ & $5.72 \pm 0.09$ & $37.58 \pm 0.49$ & 67.70 & 9.40 \\
5 & 1.60 & 45.76 & $32.35 \pm 0.76$ & $4.50 \pm 0.17$ & $41.58 \pm 0.16$ & 70.40 & 7.19 \\
6 & 1.84 & 42.87 & $30.03 \pm 1.87$ & $1.99 \pm 0.20$ & $43.70 \pm 0.31$ & 61.22 & 2.97 \\
7 & 0.72 & 68.80 & $21.57 \pm 0.47$ & $14.63 \pm 0.24$ & $30.69 \pm 0.64$ & 70.57 & 35.13 \\
8 & 1.49 & 46.40 & $26.83 \pm 0.80$ & $3.12 \pm 0.08$ & $43.23 \pm 0.51$ & 59.19 & 5.05 \\
9 & 0.37 & 86.78 & $18.44 \pm 0.01$ & $18.84 \pm 0.13$ & $27.35 \pm 1.15$ & 76.11 & 57.03 \\
10 & 1.60 & 45.27 & $32.92 \pm 0.17$ & $3.97 \pm 0.08$ & $39.82 \pm 0.16$ & 70.86 & 6.27 \\
11 & 1.24 & 54.83 & $25.73 \pm 0.93$ & $6.57 \pm 0.38$ & $36.93 \pm 1.64$ & 67.10 & 12.57 \\
12 & 1.60 & 46.69 & $25.82 \pm 0.26$ & $3.30 \pm 0.03$ & $43.52 \pm 1.56$ & 57.33 & 5.37 \\
13 & 0.54 & 75.93 & $19.00 \pm 0.57$ & $15.29 \pm 0.52$ & $31.82 \pm 0.07$ & 68.60 & 40.51 \\
14 & 2.71 & 36.84 & $32.04 \pm 0.46$ & n.d. & $54.64 \pm 1.59$ & 56.13 & 0 \\
15 & 0.02 & 76.81 & $19.47 \pm 0.89$ & $17.78 \pm 0.86$ & $30.67 \pm 0.29$ & 71.11 & 47.65 \\
16 & 1.60 & 45.80 & $28.71 \pm 0.97$ & $2.93 \pm 0.12$ & $44.09 \pm 0.60$ & 62.53 & 4.68 \\
17 & 1.60 & 45.60 & $27.72 \pm 0.34$ & $2.05 \pm 0.22$ & $44.66 \pm 0.30$ & 60.11 & 3.27 \\
18 & 2.01 & 37.64 & $32.67 \pm 1.76$ & n.d. & $52.65 \pm 1.25$ & 58.48 & 0 \\
19 & 2.84 & 38.68 & $29.54 \pm 0.43$ & n.d. & $57.32 \pm 0.19$ & 54.34 & 0 \\
20 & 1.60 & 45.74 & $28.00 \pm 1.44$ & $2.17 \pm 0.04$ & $44.88 \pm 0.74$ & 60.90 & 3.47 \\
\hline
\end{tabular}

$\mathrm{GR}_{\mathrm{S}}$ (glucose recovery in solid fractions): g glucose in solid fraction/100 g glucose in BSG

$\mathrm{HSR}_{\mathrm{S}}$ (hemicellulosic sugar recovery in solid fractions): $\mathrm{g}$ hemicellulosic sugars in solid fraction/100 $\mathrm{g}$ hemicellulosic sugars in BSG n.d.: not detected 
Table 3. Microwave pretreatment of BSG assisted by dilute sulfuric acid. Composition glucose $\left(\mathrm{GR}_{\mathrm{L}}\right)$ and hemicellulosic sugars $\left(\mathrm{HSR}_{\mathrm{L}}\right)$ in the liquid fractions.

\begin{tabular}{|c|c|c|c|c|c|c|c|c|}
\hline Run & $\mathrm{CSF}$ & $\mathrm{pH}$ & $\begin{array}{l}\text { Glucose } \\
\text { (g/L) }\end{array}$ & $\begin{array}{c}\text { Xylose } \\
(\mathrm{g} / \mathrm{L})\end{array}$ & $\begin{array}{l}\text { Arabinose } \\
(\mathrm{g} / \mathrm{L})\end{array}$ & $\begin{array}{c}\text { Oligomeric sugars } \\
(\%)\end{array}$ & $\begin{array}{l}\mathrm{GR}_{\mathrm{L}} \\
(\%)\end{array}$ & $\begin{array}{l}\mathrm{HSR}_{\mathrm{L}} \\
(\%)\end{array}$ \\
\hline 1 & 0.74 & 2.30 & $5.57 \pm 0.08$ & $9.90 \pm 0.04$ & $7.33 \pm 0.11$ & 65.29 & 24.10 & 53.19 \\
\hline 2 & 2.19 & 1.31 & $6.33 \pm 0.09$ & $16.41 \pm 0.12$ & $7.49 \pm 0.01$ & 1.26 & 27.35 & 73.79 \\
\hline 3 & 1.93 & 0.93 & $4.77 \pm 0.01$ & $18.39 \pm 0.04$ & $8.33 \pm 0.08$ & 0.23 & 20.64 & 82.51 \\
\hline 4 & -0.70 & 0.84 & $4.78 \pm 0.00$ & $16.20 \pm 0.15$ & $8.52 \pm 0.12$ & 10.69 & 20.66 & 76.30 \\
\hline 5 & 1.60 & 0.60 & $4.94 \pm 0.03$ & $19.20 \pm 0.17$ & $9.04 \pm 0.00$ & 1.34 & 21.34 & 86.92 \\
\hline 6 & 1.84 & 0.34 & $7.12 \pm 0.11$ & $17.80 \pm 0.09$ & $8.24 \pm 0.05$ & n.d. & 30.78 & 80.38 \\
\hline 7 & 0.72 & 0.88 & $4.89 \pm 0.04$ & $8.76 \pm 0.05$ & $7.12 \pm 0.08$ & 63.31 & 21.15 & 49.00 \\
\hline 8 & 1.49 & 1.06 & $6.98 \pm 0.08$ & $16.93 \pm 0.10$ & $8.02 \pm 0.06$ & 3.86 & 30.19 & 77.01 \\
\hline 9 & 0.37 & 0.52 & $1.53 \pm 0.00$ & $2.45 \pm 0.00$ & $3.27 \pm 0.02$ & 65.02 & 6.60 & 17.67 \\
\hline 10 & 1.60 & 0.53 & $4.61 \pm 0.02$ & $18.22 \pm 0.15$ & $8.59 \pm 0.01$ & 2.41 & 19.92 & 82.79 \\
\hline 11 & 1.24 & 0.35 & $5.49 \pm 0.07$ & $14.12 \pm 0.12$ & $7.87 \pm 0.04$ & 28.12 & 23.73 & 67.88 \\
\hline 12 & 1.60 & 0.53 & $6.35 \pm 0.12$ & $16.11 \pm 0.18$ & $8.22 \pm 0.08$ & 3.15 & 27.46 & 75.11 \\
\hline 13 & 0.54 & 0.28 & $3.35 \pm 0.04$ & $5.83 \pm 0.10$ & $5.68 \pm 0.06$ & 58.21 & 14.49 & 35.54 \\
\hline 14 & 2.71 & 0.50 & $7.33 \pm 0.08$ & $13.52 \pm 0.04$ & $6.62 \pm 0.07$ & n.d. & 31.70 & 62.17 \\
\hline 15 & 0.02 & 0.77 & $3.74 \pm 0.06$ & $5.02 \pm 0.01$ & $5.67 \pm 0.04$ & 65.77 & 16.15 & 33.00 \\
\hline 16 & 1.60 & 0.58 & $6.77 \pm 0.06$ & $17.20 \pm 0.17$ & $8.11 \pm 0.03$ & 2.19 & 29.28 & 78.15 \\
\hline 17 & 1.60 & 0.53 & $6.64 \pm 0.03$ & $18.29 \pm 0.10$ & $8.21 \pm 0.09$ & 1.48 & 28.71 & 81.80 \\
\hline 18 & 2.01 & 0.52 & $7.33 \pm 0.01$ & $16.41 \pm 0.12$ & $7.45 \pm 0.10$ & n.d. & 31.70 & 73.68 \\
\hline 19 & 2.84 & 0.87 & $6.50 \pm 0.15$ & $10.47 \pm 0.09$ & $5.41 \pm 0.08$ & n.d. & 28.10 & 49.02 \\
\hline 20 & 1.60 & 0.65 & $6.67 \pm 0.01$ & $17.88 \pm 0.17$ & $8.19 \pm 0.11$ & 1.10 & 28.85 & 80.49 \\
\hline
\end{tabular}

$\mathrm{GR}_{\mathrm{L}}$ (glucose recovery in liquid fractions): $\mathrm{g}$ glucose in liquid fractions/100 g glucose in BSG $\mathrm{HSR}_{\mathrm{L}}$ (hemicellulosic sugar recovery in liquid fractions): $\mathrm{g}$ hemicellulosic sugars in liquid fractions/100 g hemicellulosic sugars in BSG

n.d.: not detected 
Table 4. Microwave pretreatment of BSG assisted by dilute sulfuric acid. Composition

\begin{tabular}{ccccccc}
\hline Run & CSF & $\begin{array}{c}\text { Acetic acid } \\
(\mathrm{g} / \mathrm{L})\end{array}$ & $\begin{array}{c}\text { Formic acid } \\
(\mathrm{g} / \mathrm{L})\end{array}$ & $\begin{array}{c}\text { Furfural } \\
(\mathrm{g} / \mathrm{L})\end{array}$ & $\begin{array}{c}\text { HMF } \\
(\mathrm{g} / \mathrm{L})\end{array}$ & $\begin{array}{c}\text { Total phenols } \\
(\mathrm{g} \text { GAE/L })\end{array}$ \\
\hline 1 & 0.74 & $0.10 \pm 0.00$ & $0.01 \pm 0.00$ & n.d. & n.d. & $0.84 \pm 0.07$ \\
2 & 2.19 & $0.85 \pm 0.02$ & $0.02 \pm 0.00$ & $0.49 \pm 0.03$ & $0.17 \pm 0.01$ & $1.71 \pm 0.01$ \\
3 & 1.93 & $1.02 \pm 0.11$ & $0.06 \pm 0.01$ & $0.67 \pm 0.01$ & $0.05 \pm 0.00$ & $1.27 \pm 0.09$ \\
4 & -0.70 & $0.75 \pm 0.08$ & $0.02 \pm 0.00$ & $0.02 \pm 0.00$ & n.d. & $0.95 \pm 0.02$ \\
5 & 1.60 & $0.98 \pm 0.04$ & $0.01 \pm 0.00$ & $0.23 \pm 0.04$ & $0.02 \pm 0.00$ & $1.19 \pm 0.08$ \\
6 & 1.84 & $0.97 \pm 0.10$ & $0.02 \pm 0.00$ & $0.40 \pm 0.01$ & $0.05 \pm 0.00$ & $1.21 \pm 0.02$ \\
7 & 0.72 & $0.19 \pm 0.01$ & $0.04 \pm 0.00$ & n.d. & n.d. & $0.49 \pm 0.05$ \\
8 & 1.49 & $0.68 \pm 0.04$ & $0.02 \pm 0.00$ & $0.60 \pm 0.06$ & $0.08 \pm 0.00$ & $1.46 \pm 0.04$ \\
9 & 0.37 & $0.11 \pm 0.02$ & $0.05 \pm 0.01$ & n.d. & n.d. & $0.15 \pm 0.00$ \\
10 & 1.60 & $0.92 \pm 0.03$ & $0.02 \pm 0.00$ & $0.21 \pm 0.01$ & $0.01 \pm 0.00$ & $1.14 \pm 0.08$ \\
11 & 1.24 & $0.66 \pm 0.09$ & $0.06 \pm 0.00$ & n.d. & n.d. & $0.82 \pm 0.06$ \\
12 & 1.60 & $0.81 \pm 0.12$ & $0.05 \pm 0.00$ & $0.16 \pm 0.00$ & $0.02 \pm 0.00$ & $1.10 \pm 0.11$ \\
13 & 0.54 & $0.25 \pm 0.10$ & $0.05 \pm 0.01$ & n.d. & n.d. & $0.37 \pm 0.04$ \\
14 & 2.71 & $1.22 \pm 0.04$ & $0.05 \pm 0.01$ & $3.19 \pm 0.15$ & $0.35 \pm 0.05$ & $2.45 \pm 0.05$ \\
15 & 0.02 & $0.12 \pm 0.05$ & $0.03 \pm 0.00$ & n.d. & n.d. & $0.33 \pm 0.01$ \\
16 & 1.60 & $0.84 \pm 0.08$ & $0.02 \pm 0.00$ & $0.19 \pm 0.01$ & $0.02 \pm 0.00$ & $1.18 \pm 0.04$ \\
17 & 1.60 & $0.91 \pm 0.16$ & $0.06 \pm 0.00$ & $0.23 \pm 0.00$ & $0.03 \pm 0.00$ & $1.20 \pm 0.06$ \\
18 & 2.01 & $1.12 \pm 0.15$ & $0.17 \pm 0.02$ & $1.99 \pm 0.12$ & $0.24 \pm 0.04$ & $2.01 \pm 0.04$ \\
19 & 2.84 & $1.24 \pm 0.21$ & $0.30 \pm 0.03$ & $3.84 \pm 0.15$ & $0.56 \pm 0.08$ & $2.43 \pm 0.00$ \\
20 & 1.60 & $0.91 \pm 0.07$ & $0.02 \pm 0.00$ & $0.29 \pm 0.01$ & $0.04 \pm 0.00$ & $1.22 \pm 0.09$ \\
\hline & 15.5 & & & &
\end{tabular}

n.d.: not detected

Total phenols (g GAE/L): expressed as g gallic acid equivalent/L. 
Table 5. Microwave pretreatment of BSG assisted by dilute sulfuric acid. Enzymatic concentration $(\mathrm{g} / \mathrm{L})$ and glucose recoveries (EH glucose recovery, \%) referred to pretreated or untreated BSG. Overall sugar recoveries (\%) referred to untreated BSG.

\begin{tabular}{ccccccc}
\cline { 3 - 5 } & \multicolumn{3}{c}{$\begin{array}{c}\text { Carbohydrate concentration } \\
(\mathrm{g} / \mathrm{L})\end{array}$} & $\begin{array}{c}\text { EH glucose recovery } \\
(\%)\end{array}$ & $\begin{array}{c}\text { Overall } \\
\text { sugar }\end{array}$ \\
Run & CSF & Glucose & Xylose & $\begin{array}{c}\text { referred to } \\
\text { pretreated } \\
\text { BSG }\end{array}$ & $\begin{array}{c}\text { referred to } \\
\text { untreated } \\
\text { BSG }\end{array}$ & $\begin{array}{c}\text { recovery } \\
(\%)\end{array}$ \\
\hline 1 & 0.74 & $8.1 \pm 0.2$ & $3.0 \pm 0.1$ & 68.1 & 48.8 & 64.7 \\
2 & 2.19 & $16.0 \pm 0.5$ & $1.2 \pm 0.0$ & 88.1 & 69.7 & 80.9 \\
3 & 1.93 & $17.5 \pm 0.3$ & $1.8 \pm 0.0$ & 94.1 & 72.3 & 84.9 \\
4 & -0.70 & $14.0 \pm 0.0$ & $2.3 \pm 0.0$ & 84.3 & 67.1 & 80.8 \\
5 & 1.60 & $15.0 \pm 0.2$ & $1.9 \pm 0.0$ & 84.2 & 69.7 & 87.4 \\
6 & 1.84 & $14.2 \pm 0.6$ & $1.3 \pm 0.1$ & 85.8 & 61.7 & 83.6 \\
7 & 0.72 & $7.1 \pm 0.2$ & $3.0 \pm 0.1$ & 59.6 & 49.4 & 62.3 \\
8 & 1.49 & $14.1 \pm 0.3$ & $1.7 \pm 0.1$ & 95.7 & 66.6 & 83.9 \\
9 & 0.37 & $3.4 \pm 0.1$ & $2.1 \pm 0.1$ & 34.0 & 30.4 & 30.2 \\
10 & 1.60 & $15.8 \pm 0.3$ & $2.0 \pm 0.1$ & 87.3 & 72.7 & 85.6 \\
11 & 1.24 & $10.3 \pm 0.4$ & $2.5 \pm 0.2$ & 72.5 & 57.2 & 74.7 \\
12 & 1.60 & $12.7 \pm 0.0$ & $1.9 \pm 0.2$ & 89.5 & 60.3 & 79.8 \\
13 & 0.54 & $4.9 \pm 0.2$ & $2.2 \pm 0.0$ & 46.8 & 37.7 & 46.3 \\
14 & 2.71 & $16.7 \pm 0.8$ & $0.3 \pm 0.0$ & 94.5 & 62.3 & 71.9 \\
15 & 0.02 & $4.6 \pm 0.0$ & $2.1 \pm 0.0$ & 43.3 & 36.2 & 44.6 \\
16 & 1.60 & $14.2 \pm 1.1$ & $1.7 \pm 0.1$ & 89.6 & 65.9 & 83.9 \\
17 & 1.60 & $14.1 \pm 0.2$ & $1.5 \pm 0.0$ & 92.1 & 65.1 & 85.3 \\
18 & 2.01 & $18.1 \pm 0.7$ & $0.5 \pm 0.0$ & 100.0 & 69.2 & 81.4 \\
19 & 2.84 & $15.6 \pm 0.2$ & $0.3 \pm 0.0$ & 96.1 & 61.3 & 62.4 \\
20 & 1.60 & $14.6 \pm 0.0$ & $1.5 \pm 0.0$ & 94.6 & 67.7 & 85.5 \\
\hline
\end{tabular}

EH glucose recovery, \% (referred to pretreated BSG): g glucose by enzymatic hydrolysis/100 g glucose (contained as cellulose) in pretreated BSG.

EH glucose recovery, \% (referred to untreated BSG): g glucose by enzymatic hydrolysis/100 g glucose (contained as cellulose) in untreated BSG.

Overall sugar recovery (\%): sum of glucose and xylose grams in enzymatic hydrolyzates and pretreatment liquid /100 $\mathrm{g}$ total sugars in untreated BSG. 
Table 6. Pretreatment of BSG by microwave assisted dilute sulfuric acid under optimal experimental run: composition of solid and liquid fractions.

\begin{tabular}{|c|c|}
\hline Component & Concentration \\
\hline \multicolumn{2}{|c|}{ Solid fraction $(\%)$} \\
\hline Cellulose & $24.54 \pm 0.23$ \\
\hline Xylan & $1.35 \pm 0.02$ \\
\hline Arabinan & n.d. \\
\hline Lignin & $47.82 \pm 1.25$ \\
\hline \multicolumn{2}{|c|}{ Liquid fraction $(\mathrm{g} / \mathrm{L})$} \\
\hline \multicolumn{2}{|c|}{ Sugars } \\
\hline Glucose & $7.32 \pm 0.15$ \\
\hline Xylose & $17.74 \pm 0.22$ \\
\hline Arabinose & $8.50 \pm 0.19$ \\
\hline \multicolumn{2}{|c|}{ Inhibitors } \\
\hline Furfural & $0.27 \pm 0.04$ \\
\hline HMF & $0.04 \pm 0.00$ \\
\hline Formic acid & $0.02 \pm 0.00$ \\
\hline Acetic acid & $0.90 \pm 0.09$ \\
\hline Total phenols & $1.19 \pm 0.14$ \\
\hline
\end{tabular}


Table 7. Composition of slurry enzymatic hydrolysates (SEH) before and after

detoxification individually with activated charcoal or ion-exchange resins.

\begin{tabular}{|c|c|c|c|c|c|c|c|c|}
\hline & \multicolumn{3}{|c|}{ Carbohydrates $(\mathrm{g} / \mathrm{L})$} & \multicolumn{5}{|c|}{ Inhibitors (g/L) } \\
\hline & Glucose & Xylose & Arabinose & $\begin{array}{c}\text { Acetic } \\
\text { acid }\end{array}$ & $\begin{array}{c}\text { Formic } \\
\text { acid }\end{array}$ & Furfural & $\mathrm{HMF}$ & $\begin{array}{c}\text { Total } \\
\text { phenols }\end{array}$ \\
\hline SEH_10\% & $20.7 \pm 0.1$ & $18.9 \pm 0.1$ & $7.9 \pm 0.0$ & $1.0 \pm 0.0$ & $0.1 \pm 0.0$ & $0.1 \pm 0.0$ & n.d. & $1.0 \pm 0.1$ \\
\hline EH_10\%-ACD (2\%) & $19.4 \pm 0.2$ & $17.7 \pm 0.0$ & $7.5 \pm 0.1$ & $0.9 \pm 0.0$ & $0.1 \pm 0.0$ & n.d. & n.d. & $0.3 \pm 0.0$ \\
\hline SEH_10\%-RD (2\%) & $19.0 \pm 0.1$ & $17.8 \pm 0.1$ & $7.5 \pm 0.1$ & $1.0 \pm 0.0$ & $0.1 \pm 0.0$ & n.d. & n.d. & $0.6 \pm 0.0$ \\
\hline SEH_15\% & $33.7 \pm 0.3$ & $28.4 \pm 0.2$ & $11.8 \pm 0.0$ & $1.6 \pm 0.1$ & n.d. & $0.7 \pm 0.0$ & $0.1 \pm 0.0$ & $1.8 \pm 0.1$ \\
\hline EH_15\%-ACD (5\%) & $33.4 \pm 0.1$ & $28.0 \pm 0.0$ & $11.6 \pm 0.0$ & $1.4 \pm 0.1$ & n.d. & n.d. & n.d. & $0.3 \pm 0.0$ \\
\hline SEH_15\%-RD (10\%) & $30.7 \pm 0.0$ & $27.6 \pm 0.2$ & $11.2 \pm 0.1$ & $1.6 \pm 0.0$ & n.d. & n.d. & n.d. & $0.7 \pm 0.0$ \\
\hline
\end{tabular}

SEH: slurry enzymatic hydrolysate

ACD: activated charcoal detoxification

$\mathrm{RD}$ : ion-exchange resin detoxification

n.d.: not detected 
Table 8. ABE fermentation of the slurry enzymatic hydrolysates detoxified with

activated charcoal or ion-exchange resins, resulting from the enzymatic hydrolysis of the whole slurry obtained under optimal pretreatment conditions. Initial monosaccharide concentration $(\mathrm{g} / \mathrm{L})$, acetic and butyric acid concentrations $(\mathrm{g} / \mathrm{L})$ at the end of fermentation, butanol and $\mathrm{ABE}$ yields ( $\mathrm{Y}_{\mathrm{BUT} / \text { sugars, }}, \mathrm{Y}_{\mathrm{ABE} / \text { sugars }}$ expressed as $\mathrm{g} / \mathrm{g}$ sugars consumed), and butanol and ABE productivities ( $\mathrm{P}_{\mathrm{BUT}}, \mathrm{P}_{\mathrm{ABE}}$ expressed as $\mathrm{g} / \mathrm{L} \cdot \mathrm{h}$ ) at the time of maximum production of butanol and ABE.

\begin{tabular}{|c|c|c|c|c|c|c|c|c|}
\hline & $\begin{array}{c}\mathrm{t} \\
(\mathrm{h})\end{array}$ & $\begin{array}{c}\text { Sugar } \\
\text { uptake } \\
(\%)\end{array}$ & $\begin{array}{c}\text { Acetic } \\
\text { acid } \\
(\mathrm{g} / \mathrm{L})\end{array}$ & $\begin{array}{c}\text { Butyric } \\
\text { acid } \\
(\mathrm{g} / \mathrm{L})\end{array}$ & $\begin{array}{l}Y_{\text {BUT/sugars }} \\
\quad(\mathrm{g} / \mathrm{g})\end{array}$ & $\begin{array}{l}Y_{\mathrm{ABE} / \text { sugars }} \\
(\mathrm{g} / \mathrm{g})\end{array}$ & $\begin{array}{c}\text { PBUT }_{\text {BUT }} \\
(\mathrm{g} / \mathrm{L} \cdot \mathrm{h})\end{array}$ & $\begin{array}{c}\mathrm{P}_{\mathrm{ABE}} \\
(\mathrm{g} / \mathrm{L} \cdot \mathrm{h})\end{array}$ \\
\hline \multicolumn{9}{|l|}{$\begin{array}{l}\text { Activated charcoal } \\
\text { detox }\end{array}$} \\
\hline SEH_10\%-ACD (2\%) & 48 & $97.0 \pm 0.4$ & $0.4 \pm 0.0$ & $0.2 \pm 0.0$ & 0.26 & 0.37 & 0.198 & 0.285 \\
\hline SEH_15\%-ACD (5\%) & 72 & $87.2 \pm 0.3$ & $0.4 \pm 0.0$ & $0.0 \pm 0.0$ & 0.21 & 0.32 & 0.175 & 0.259 \\
\hline \multicolumn{9}{|l|}{$\begin{array}{c}\text { Ion-exchange resins } \\
\text { detox }\end{array}$} \\
\hline SEH_10\%-RD (2\%) & 48 & $97.9 \pm 0.6$ & $0.5 \pm 0.0$ & $0.3 \pm 0.0$ & 0.24 & 0.35 & 0.194 & 0.291 \\
\hline SEH_15\%-RD (10\%) & 72 & $90.9 \pm 0.7$ & $0.5 \pm 0.0$ & $0.1 \pm 0.1$ & 0.22 & 0.33 & 0.178 & 0.273 \\
\hline
\end{tabular}
ACD: activated charcoal detoxification $\mathrm{RD}$ : ion-exchange resin detoxification 


\section{Figure captions}

Fig. 1. Response surface plots representing the interactive effect of temperature and pretreatment time at $1 \% \mathrm{H}_{2} \mathrm{SO}_{4}$ on the hemicellulosic sugar recovery $\left(\mathrm{HSR}_{\mathrm{L}}\right)(\mathrm{a}), \mathrm{EH}$ glucose recovery (referred to untreated BSG) (c) and total inhibitor concentration in the liquid fraction (e). Response surface plots representing the interactive effect of temperature and sulfuric acid concentration for $6 \mathrm{~min}$ on the hemicellulosic sugar recovery $\left(\mathrm{HSR}_{\mathrm{L}}\right)(\mathrm{b}), \mathrm{EH}$ glucose recovery (referred to untreated BSG) (d) and total inhibitor concentration in the liquid fraction (f).

Fig. 2. ABE fermentation of the slurry enzymatic hydrolysate (SEH) detoxified with activated charcoal (a) or ion-exchange resins (b).

Fig. 3. Mass balance flow diagram of the overall ABE production process from slurry enzymatic hydrolysates (SEH) detoxified with activated charcoal, using a pretreatment solid load of $10 \%(w / v)(a)$ and $15 \%(w / v)(b)$. 

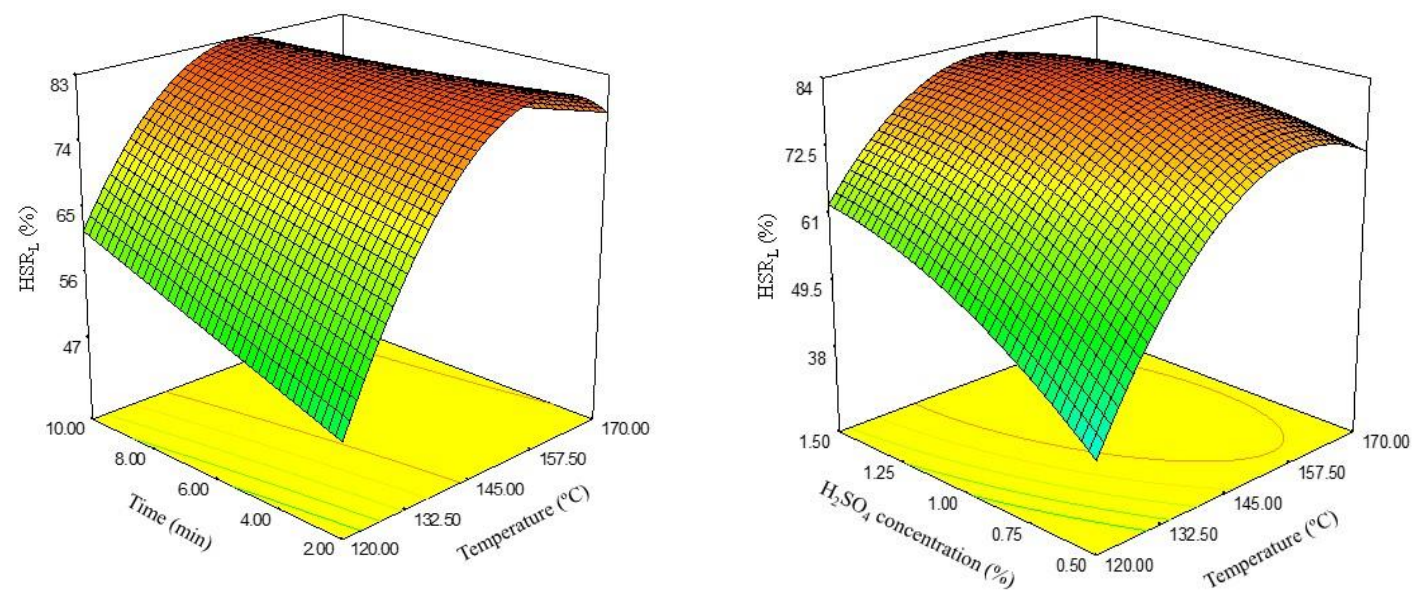

a)

b)
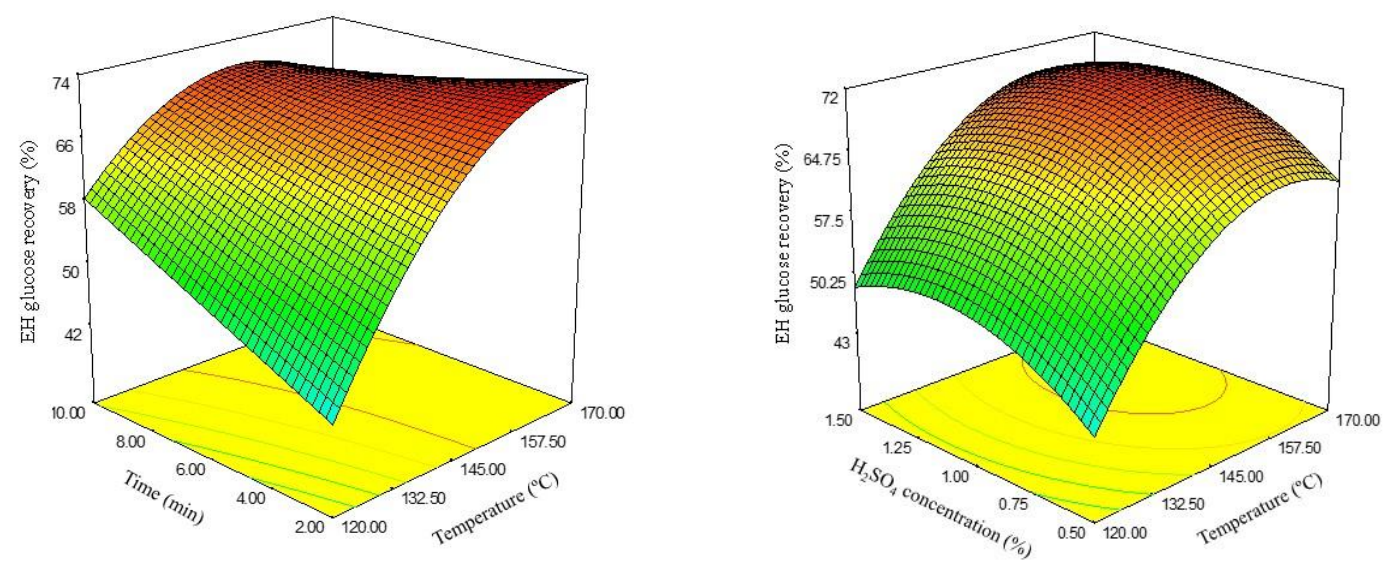

c)

d)
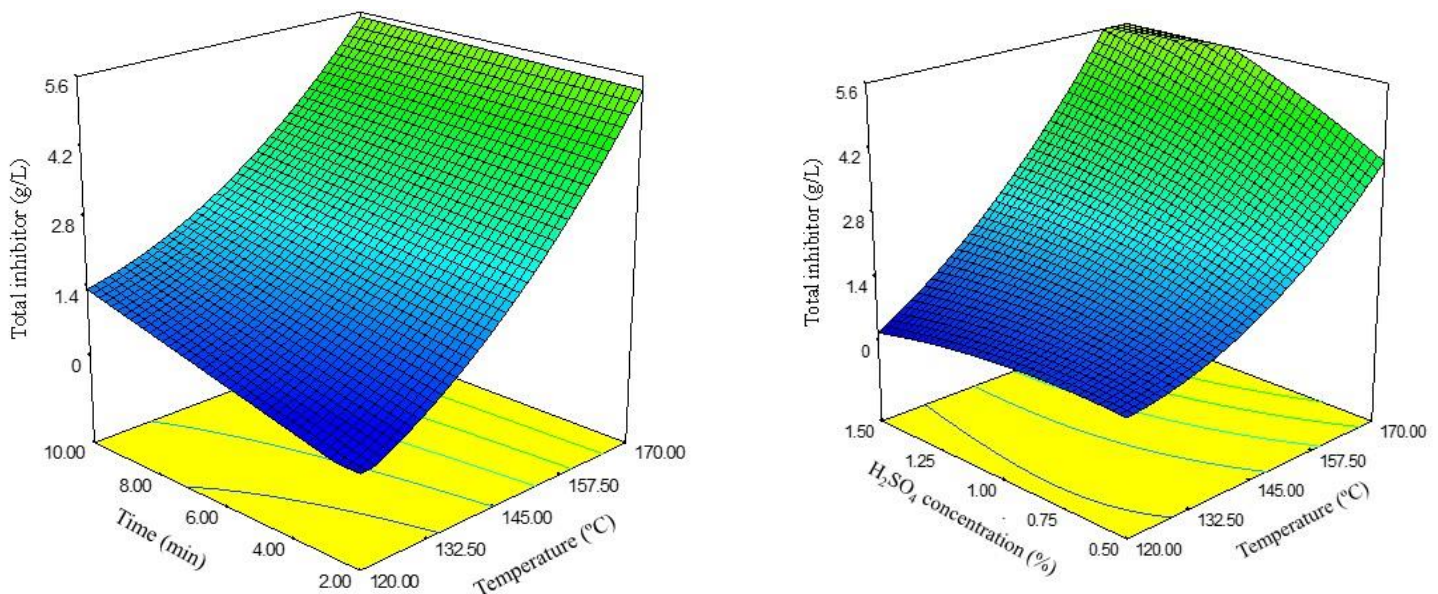

e)

f)

Fig. 1. 


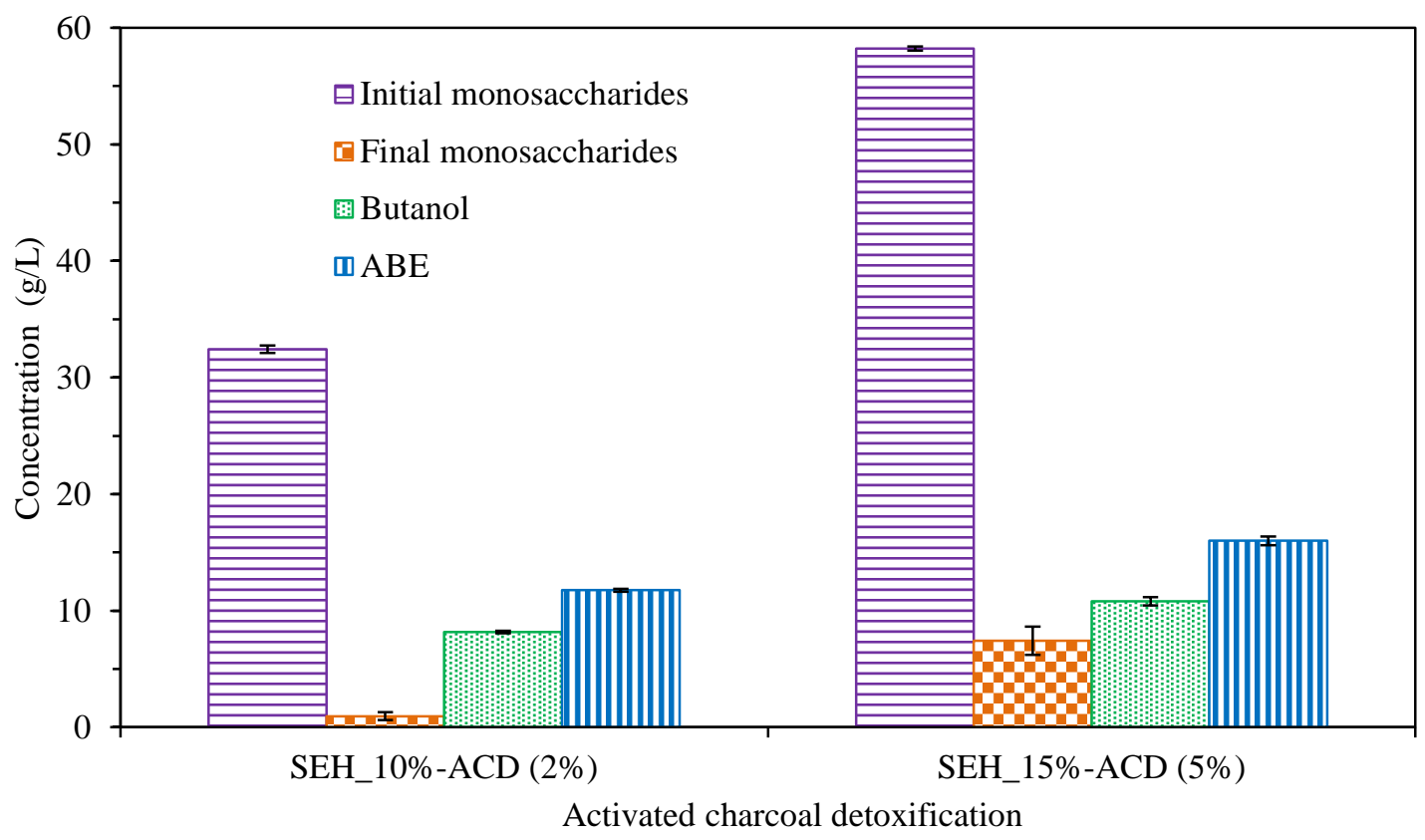

a)

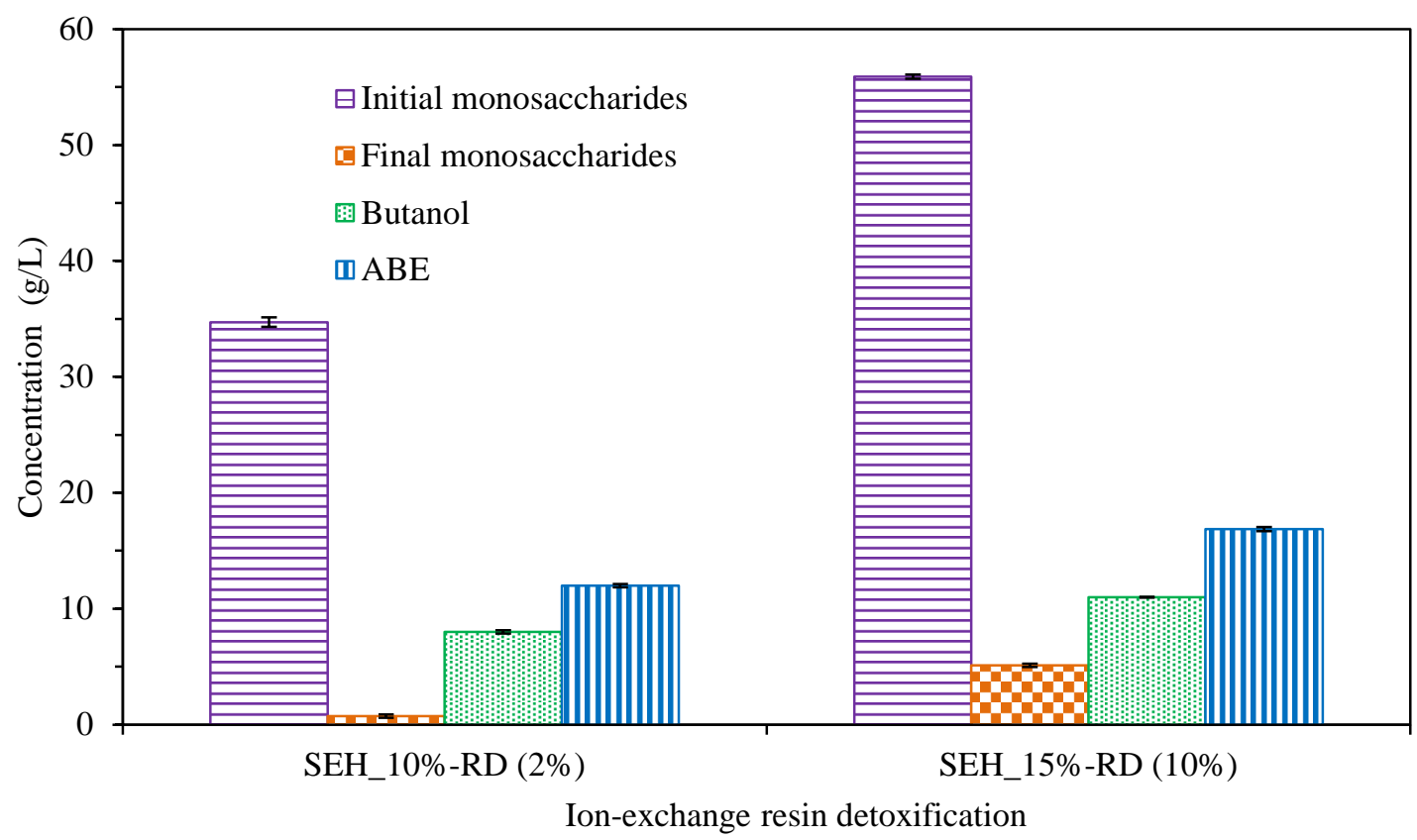

b)

SEH: slurry enzymatic hydrolysate

ACD: activated charcoal detoxification

$\mathrm{RD}$ : ion-exchange resin detoxification

Fig. 2. 
$\mathrm{H}_{2} \mathrm{SO}_{4}(96 \%) 131 \mathrm{~g}$ $\mathrm{H}_{2} \mathrm{O} 9869 \mathrm{~g}$

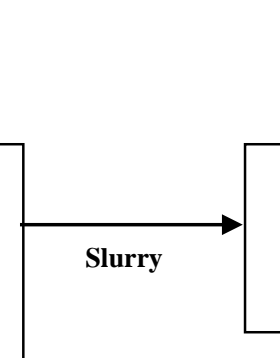
$10 \% \mathrm{w} / \mathrm{v}$

PETREATMENT

$\mathrm{H}_{2} \mathrm{SO}_{4} 1.26 \% \mathrm{w} / \mathrm{v}$
Cellic CTec2 $81 \mathrm{~g}$

$\mathrm{NaOH}(96 \%) 70 \mathrm{~g}$

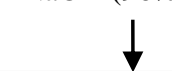

ENZYMATIC HYDROLYSIS $\begin{array}{llll}50^{\circ} \mathrm{C} & 48 \mathrm{~h} & \mathrm{pH} & 4.8\end{array}$ $150 \mathrm{rpm} \quad 4.8 \% \mathrm{w} / \mathrm{v}$

.

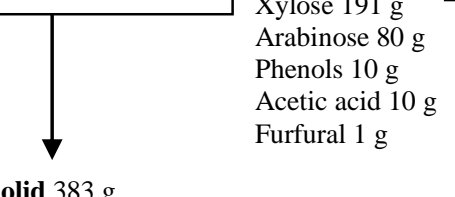

Solid $383 \mathrm{~g}$

Glucose $19 \mathrm{~g}$ Xylose $1 \mathrm{~g}$
Lignin $235 \mathrm{~g}$ b)

50 Glucose $210 \mathrm{~g}$ 51 Xylose $234 \mathrm{~g}$ 52 Arabinose $90 \mathrm{~g}$ 53 Lignin $258 \mathrm{~g}$

54

Fig. 3.
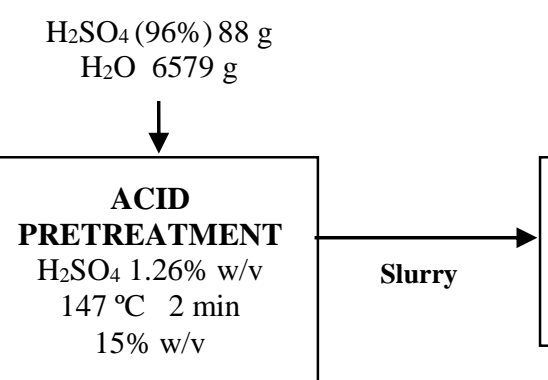

Cellic CTec2 88 g $\mathrm{NaOH}(96 \%) 74 \mathrm{~g}$

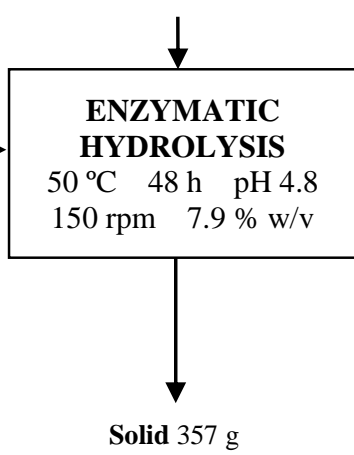

Glucose $17 \mathrm{~g}$

Xylose $3 \mathrm{~g}$

Lignin $228 \mathrm{~g}$
Activated charcoal $338 \mathrm{~g}$

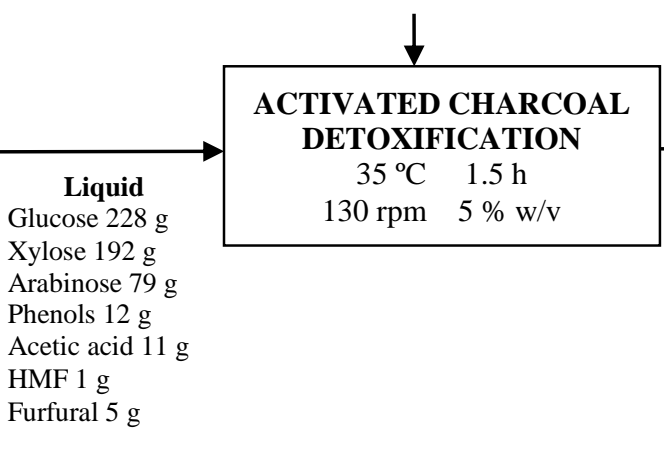

$\mathrm{NaOH}(96 \%) 12 \mathrm{~g}$

Inoculum (C. beijerinckii) $1 \mathrm{~g}$

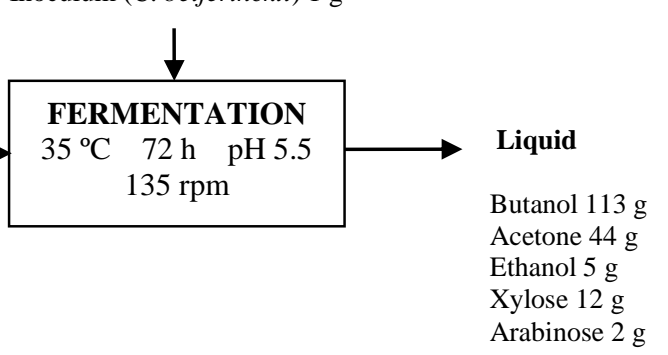

$\mathrm{NaOH}(96 \%) 16 \mathrm{~g}$ Inoculum (C. beijerinckii) $1 \mathrm{~g}$

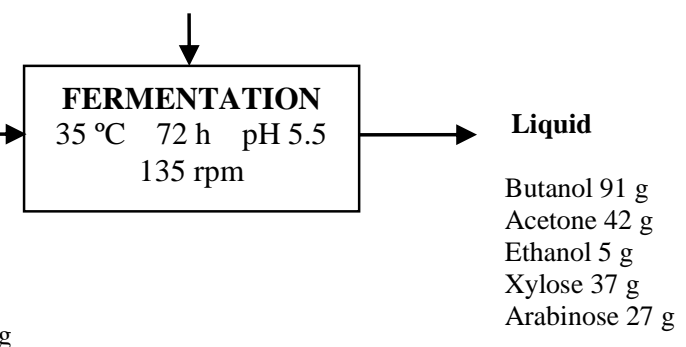




\section{SUPPLEMENTARY MATERIAL}

1

${ }_{3}^{2}$ Table 1S. Results obtained from the analysis of variance for the responses a) HSR $\mathrm{L}$, b) EH glucose 3

4

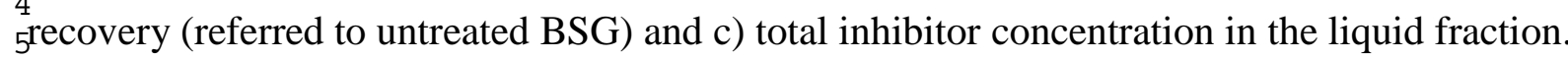

6 $7 a$

\begin{tabular}{|c|c|c|c|c|c|c|c|}
\hline $\begin{array}{l}8 \\
9 \\
\end{array}$ & Source & $\begin{array}{l}\text { Sum of } \\
\text { squares }\end{array}$ & $\begin{array}{c}\text { Degrees of } \\
\text { freedom }\end{array}$ & Mean square & F-value & $\begin{array}{c}\mathrm{p} \text {-value } \\
(\text { Prob > F })\end{array}$ & Remarks \\
\hline 10 & Model & 6174.52 & 7 & 882.07 & 46.64 & $<0.0001$ & Significant \\
\hline 11 & Temperature $(\mathrm{T})$ & 1130.27 & 1 & 1130.27 & 59.77 & $<0.0001$ & \\
\hline 12 & Time $(\mathrm{t})$ & 35.72 & 1 & 35.72 & 1.89 & 0.1967 & \\
\hline $\begin{array}{l}12 \\
13\end{array}$ & $\mathrm{H}_{2} \mathrm{SO}_{4}$ conc. $(\mathrm{C})$ & 332.46 & 1 & 332.46 & 17.58 & 0.0015 & \\
\hline 13 & $\mathrm{Tt}$ & 180.29 & 1 & 180.29 & 9.53 & 0.0103 & \\
\hline 14 & $\mathrm{TC}$ & 316.35 & 1 & 316.35 & 16.73 & 0.0018 & \\
\hline 15 & $\mathrm{~T}^{2}$ & 3747.75 & 1 & 3747.75 & 198.17 & $<0.0001$ & \\
\hline 16 & $\mathrm{C}^{2}$ & 272.48 & 1 & 272.48 & 14.41 & 0.0030 & \\
\hline 17 & Residual & 208.03 & 11 & 18.91 & - & - & \\
\hline 18 & Lack of Fit & 126.15 & 6 & 21.03 & 1.28 & 0.4009 & Not significant \\
\hline 19 & Pure Error & 81.87 & 5 & 16.37 & - & - & \\
\hline 20 & Cor Total & 6382.54 & 18 & - & - & - & \\
\hline 21 & $R$-squared & 0.9674 & - & Adj R-squared ${ }^{a}$ & 0.9467 & - & \\
\hline 22 & Mean & 67.41 & - & Pred R-squared ${ }^{b}$ & 0.8612 & - & \\
\hline 23 & C.V. $\%$ c & 6.45 & - & Adeq Precision $^{\mathrm{d}}$ & 23.095 & - & \\
\hline $24^{b)}$ & & & & & & & \\
\hline 25 & Source & $\begin{array}{l}\text { Sum of } \\
\text { squares }\end{array}$ & $\begin{array}{l}\text { Degrees of } \\
\text { freedom }\end{array}$ & Mean square & F-value & $\begin{array}{c}\text { p-value } \\
(\text { Prob > F) }\end{array}$ & Remarks \\
\hline 20 & Model & 2704.70 & 6 & 450.78 & 66.09 & $<0.0001$ & Significant \\
\hline $\begin{array}{l}27 \\
28\end{array}$ & Temperature $(\mathrm{T})$ & 1041.81 & 1 & 1041.81 & 152.75 & $<0.0001$ & \\
\hline 28 & Time $(\mathrm{t})$ & 43.42 & 1 & 43.42 & 6.37 & 0.0302 & \\
\hline 29 & $\mathrm{H}_{2} \mathrm{SO}_{4}$ conc. (C) & 41.64 & 1 & 41.64 & 6.11 & 0.0331 & \\
\hline 30 & $\mathrm{Tt}$ & 228.71 & 1 & 228.71 & 33.53 & 0.0002 & \\
\hline 31 & $\mathrm{~T}^{2}$ & 939.33 & 1 & 939.33 & 137.72 & $<0.0001$ & \\
\hline 32 & $\mathrm{C}^{2}$ & 151.02 & 1 & 151.02 & 22.14 & 0.0008 & \\
\hline 33 & Residual & 68.20 & 10 & 6.82 & - & - & \\
\hline 34 & Lack of Fit & 30.63 & 6 & 5.11 & 0.54 & 0.7597 & Not significant \\
\hline 35 & Pure Error & 37.57 & 4 & 9.39 & - & - & \\
\hline 36 & Cor Total & 2772.90 & 16 & - & - & - & \\
\hline $\begin{array}{l}36 \\
27\end{array}$ & $R$-squared & 0.9754 & - & Adj R-squared ${ }^{a}$ & 0.9606 & - & \\
\hline $\begin{array}{l}37 \\
30\end{array}$ & Mean & 59.55 & - & Pred R-squared ${ }^{b}$ & 0.9293 & - & \\
\hline 38 & C.V. $\%^{c}$ & 4.39 & - & Adeq Precision ${ }^{\mathrm{d}}$ & 25.420 & - & \\
\hline $39 c)$ & & & & & & & \\
\hline $\begin{array}{l}40 \\
41\end{array}$ & Source & $\begin{array}{l}\text { Sum of } \\
\text { squares }\end{array}$ & $\begin{array}{c}\text { Degrees of } \\
\text { freedom }\end{array}$ & Mean square & F-value & $\begin{array}{c}\text { p-value } \\
(\text { Prob > F })\end{array}$ & Remarks \\
\hline 42 & Model & 81.88 & 8 & 10.24 & 554.29 & $<0.0001$ & Significant \\
\hline 43 & Temperature $(\mathrm{T})$ & 45.89 & 1 & 45.89 & 2485.06 & $<0.0001$ & \\
\hline 44 & Time $(\mathrm{t})$ & 1.80 & 1 & 1.80 & 97.59 & $<0.0001$ & \\
\hline 45 & $\mathrm{H}_{2} \mathrm{SO}_{4}$ conc. $(\mathrm{C})$ & 2.03 & 1 & 2.03 & 110.13 & $<0.0001$ & \\
\hline 46 & $\mathrm{Tt}$ & 0.40 & 1 & 0.40 & 21.92 & 0.0011 & \\
\hline 47 & $\mathrm{TC}$ & 2.85 & 1 & 2.85 & 154.19 & $<0.0001$ & \\
\hline 48 & $\mathrm{tC}$ & 1.81 & 1 & 1.81 & 98.02 & $<0.0001$ & \\
\hline 49 & $\mathrm{~T}^{2}$ & 6.56 & 1 & 6.56 & 355.03 & $<0.0001$ & \\
\hline 59 & $\mathrm{C}^{2}$ & 0.65 & 1 & 0.65 & 35.32 & 0.0002 & \\
\hline 50 & Residual & 0.17 & 9 & 0.018 & - & - & \\
\hline 51 & Lack of Fit & 0.08 & 4 & 0.020 & 1.18 & 0.4201 & Not significant \\
\hline 52 & Pure Error & 0.09 & 5 & 0.017 & - & - & \\
\hline 53 & Cor Total & 82.05 & 17 & - & - & - & \\
\hline 54 & $R$-squared & 0.9980 & - & Adj R-squared ${ }^{a}$ & 0.9962 & - & \\
\hline 55 & Mean & 2.77 & - & Pred R-squared ${ }^{b}$ & 0.9835 & - & \\
\hline 56 & C.V. $\%{ }^{\mathrm{c}}$ & 4.90 & - & Adeq Precision ${ }^{\mathrm{d}}$ & 83.838 & - & \\
\hline
\end{tabular}

\section{$57_{B: \text { : Temperature }}$ (min).}

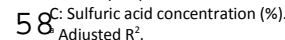

$59^{\text {Predicted } R^{2} \text {. }}$

59 c Coefficient of variation.

60 'Adequate precision. 